\title{
A EXPULSÃO DO ÉDEN: MIGRAÇÃO E ESCRITA DEPOIS DO PARAÍSO
}

\begin{abstract}
Ottmar Ette
Resumo: A temática da migração está intimamente vinculada à história humana, desde a narrativa bíblica da expulsão do paraíso. O ser humano não apenas empregou técnicas cada vez mais sofisticadas para a violência, como também transmitiu, através dos séculos, técnicas de conservação e uso de seu saberconviver. Nesse sentido móvel da história, e em consonância com as literaturas do mundo, a partir de suas diversas origens, é possível dizer que existe um "Homo migrans" desde que existe o "Homo sapiens". Assim, é possível afirmar que as ideias territoriais ou territorializantes com proveniência histórico-espacial permitem, vez ou outra, reconhecer seus esforços para filtrar e isolar a dimensão histórico-móvel e vetorial da história como narrativa, para tentar construir, com a ajuda de ideias estáticas, novos lugares da promessa ou da perda, da abundância ou da queda.
\end{abstract}

Palavras-chave: Migração; saberconviver; literaturas do mundo.

Resumen: El tema de la migración está estrechamente vinculado a la historia de la humanidad, desde la narrativa bíblica de la expulsión del paraíso. El ser humano no sólo ha empleado técnicas cada vez más sofisticadas para ejercer la violencia, sino que también ha transmitido, a lo largo de los siglos, técnicas de conservación y utilización de su saberconvivir. En este sentido móvil de la historia, y en consonancia con las literaturas del mundo, desde sus diversos orígenes, se puede decir que hay un "Homo migrans" desde que existe el "Homo sapiens". Así, es posible afirmar que las ideas territoriales o territorializadoras de procedencia histórico-espacial permiten, una y otra vez, reconocer sus esfuerzos por filtrar y aislar la dimensión histórico-móvil y vectorial de la historia como narrativa, para intentar construir, con la ayuda de las ideas estáticas, nuevos lugares de promesa o de pérdida, de abundancia o de caída.

Palabras clave: Migración; saberconvivir; literaturas del mundo.

1 Nota da tradução: Tradução ao português realizada por Luciane Alves, a partir da versão espanhola de Vicente Bernaschina Schürmann para o texto original em alemão. O texto em português foi integralmente traduzido a partir da citada versão, feitas traduções livres para as citações, com exceção das passagens bíblicas. Em nota, o tradutor da versão espanhola adverte que a maior parte das citações apresentadas por Ottmar Ette foram traduzidas pelo próprio autor. Em algumas passagens da tradução de Schürmann, indicadas em nota de rodapé, foram inseridas citações a partir de versões em espanhol dos textos.

2 Ottmar Ette é professor de Filologia Românica e Literatura Comparada na Universidade de Potsdam (Alemanha). Doutorou-se em 1990 pela Universidade de Freiburg. Professor convidado em universidades latino-americanas, europeias e dos Estados Unidos. E-mail: ette@uni-potsdam.de 


\section{CAMINHOS DO JARDIM DO SABER}

No princípio de toda a história, no princípio de todas as histórias de transumância e migração se encontram, na tradição judaico-cristã, antes de diversas emigrações e imigrações, a expulsão e o exílio. Por causa disso, talvez a imagem da expulsão do paraíso de Adão e Eva também possa abrir e iluminar neste livro as possibilidades, as fronteiras e os desafios de conviver, as projeções e perspectivas da convivência. ${ }^{3}$ O Gênesis 3, 21-24 resume a dura e impiedosa conclusão do castigo que Adão e Eva receberam por sua infração: haver comido da árvore do conhecimento:

21- Iahweh Deus fez para o homem e sua mulher túnicas de pele, e os vestiu.

22 - Depois disse Iahweh Deus: "Se o homem já é como um de nós, versado no bem e no mal, que agora ele não estenda a mão e colha também da árvore da vida, e coma e viva para sempre!

23 - E Iahweh Deus o expulsou do jardim do Éden para cultivar o solo de onde foi tirado.

24 - Ele baniu o homem e colocou, diante do jardim do Éden, os querubins e a chama da espada fulgurante para guardar o caminho da árvore da vida. ${ }^{4}$

Este julgamento divino é, como tal, definitivo, e perdura na sucessão das gerações humanas através da proibição de voltar a essa terra localizada à oeste do Leste do Edén. De fato, o regresso só é possível depois da morte, através da própria terra que o homem deve cultivar sem descanso para alimentar a si e aos seus "Com o suor de teu rosto / comerás teu pão / até que retornes ao solo, / pois dele foste tirado. / Pois tu és pó/ E ao pó tornarás." $\left(\right.$ Génesis 3, 19) ${ }^{5}$

De tal modo, fica determinado, de uma vez por todas, o castigo de Adão e Eva, que é também de toda sua descendência: não existe apelação possível, e uma libertação virtual desta condição de banidos - talvez por bom comportamento - também não está prevista. A expulsão do primeiro homem do Paraíso é uma migração forçada, sem retorno enquanto dure a vida.

Já que somente com a morte termina e se fecha o ciclo da vida, e somente com ela é que

3 Ver sobre isso as reflexões fundamentais em Ette, Ottmar: ZusammenLebensWissen. List, Last und Lust literarischer Konvivenz im globalen Maßstab. ÜberLebensWissen III. Berlin: Kulturverlag Kadmos 2010.

4 Bíblia de Jerusalém. Tradução direta dos originais. $5^{a}$ impressão. São Paulo: Paulus, 2008. p. 38-39.

5 Sobre a problemática da terra a ser cultivada pode ser consultado o comentário de Scharbert, Josef: Die neue Echter Bibel. Kommentar zum Alten Testament mit der Einheitsübersetzung. Würzburg: Echter Verlag 1983, S. 61; em relação à narração do fratricídio que segue e que comentarei a continuação, ver também a página 67. Recomendo ainda os seguintes textos: Ruppert, Lothar: Genesis: ein kritischer und theologischer Kommentar. Würzburg: Echter Verlag 2003 tanto como Soggin, Jan Alberto: Das Buch Genesis: Kommentar. Darmstadt: Wissenschaftliche Buchgesellschaft 1997. Como referências mais gerais, refiro também Schmidt, Hans-Peter / Weidner, Daniel (Hg.): Bibel als Literatur. München: Fink 2011. Agradeço a Gesine Müller pelos inumeráveis conselhos e comentários sobre o texto. 
aquele ser feito de pó se desfaz em pó e, talvez, algum dia - mas quem pode saber? -, graças a uma misericordiosa tempestade, o vento o sopre em regresso àqueles campos que teve então que deixar sob a ameaça da espada em chamas, que o aguardava caso tentasse voltar. A conditio humana, também a dos humanos modernos, é a de desterro: sem esperança de regresso à casa enquanto dure a vida.

Assim como Iahweh pôs originalmente o homem no jardim do Éden, "para o cultivar e guardar" (Génesis 2,15), da mesma forma é ele quem o expulsa, no momento em que toma consciência de que o homem rompeu as leis divinas: "mas da árvore do conhecimento do bem e do mal não comerás, porque no dia em que dela comeres terás que morrer..." (Génesis 2, 17)

Sem podermos adentrar por hora as diferenças sexuais e de gênero introduzidas entre Adão e Eva, onde esta última fica marcada como a sedutora sob influência da serpente, nem discutir o fato de que provar a fruta do conhecimento não seja castigado com uma morte instantânea, de todo modo é possível sustentar que este acesso forçado dos seres humanos à árvore do conhecimento e seus frutos não traz consigo nem a morte imediata nem a consequência instantânea de um estado de felicidade. Desde então, poderíamos dizer, é que o conhecimento está ligado a uma questão de tempo, a um trabalho árduo e a um saber doloroso, e que não se dirige a uma felicidade da qual o ser humano possa participar durante sua vida.

Mas isso não é tudo. A infração desse veto divino, cometida pelos humanos com ajuda da serpente, carrega consigo a dimensão de uma violência que não fica somente na ameaça latente de sua execução futura (como seria uma pena de morte, cuja execução imediata ainda não chega) e que, por isso mesmo, cabe designá-la desde o início como a própria violência; ou melhor ainda, como o ponto de emergência oculto de um sistema de violência que se estende ao longo da história dos homens e da humanidade. Pois bem, quando e como começa essa violência?

Em dois de setembro de 1978, o jornal protestante Réforme publicou uma entrevista ao semiólogo e teórico cultural Roland Barthes, na qual ele diferenciava dois tipos fundamentais de violência. Ali, nomeava como primeira a violência ancorada em cada imposição que se exerce a partir de uma coletividade (prepotente) sobre o indivíduo, ou seja, uma violência da lei e do Estado, e que pode descrever-se como violence de la contrainte ${ }^{6}$, como a "violência restritiva" (ou também coercitiva). Barthes distingue desse outro tipo de violência exercida diretamente sobre o corpo dos indivíduos, que pode aparecer seja como variante da "violência carcerária" (violence carcérale) ou como da "violência sangrenta" (violence sanglante) ${ }^{7}$, e que comumente se expressa no confinamento, tortura ou aniquilação do corpo. Ambos os tipos de violência estão, no entanto, intimamente relacionados e geram em sua interação um système infini, um sistema ininterrupto e talvez interrompível de violência, na medida em que a violência se renova constantemente nesta circulação sem fim. ${ }^{8}$

Ao recorrer a uma conceitualização como essa, é possível reconhecer, na clara proibi-

6 Barthes, Roland: "Propos sur la violence". En : Oeuvres complètes. Edition établie et présentée par Eric Marty. 3 Tomos. Paris: Seuil 1993-1995, aquí Tomo. III, p. 903.

7 Ibid.

8 Ibid, p. 904. 
ção de provar o fruto da árvore do conhecimento, uma violence de contrainte, baseada em uma relação assimétrica entre Deus e o ser humano, que depois da expulsão do primeiro homem do Jardim do Éden - que é ao mesmo tempo a expulsão do Jardim de um conhecimento certamente não puro, mas sim maduro - conduz a uma violência corporal, que põe violentamente em movimento a história da humanidade. No movimento de expulsão, tanto como no dos expulsos, começa a ganhar velocidade uma história em que a violência - e aqui radica um conhecimento muito doloroso, que o reconhecimento do bem e do mal afirma e coloca em questão ao mesmo tempo - está igualmente inscrita desde sempre. A história e a violência parecem não ser separáveis.

A consequência lógica de um "começo" assim da história humana, sob o signo da expulsão e da violência, é que a mecânica espacial de exclusão da violence carcérale prontamente se transforma em uma violence sanglante, como se expressa figurativamente no episódio do primeiro fratricídio da história da humanidade. O Gênesis 4, 10-16 mostra de que maneira a espiral de violência e expulsão previsivelmente girou mais uma vez na história do fratricídio. Iahweh, o Deus todo poderoso, amaldiçoa o assassino que leva o nome de Caim:

10 - Iahweh disse: "Que fizeste! Ouço o sangue de teu irmão, do solo, clamar para mim!

11- Agora, és maldito e expulso do solo fértil que abriu a boca para receber de tua mão o sangue de teu irmão.

12 - Ainda que cultives o solo, ele não te dará mais seu produto: serás um fugitivo errante sobre a terra."

13 - Então Caim disse a Iahweh: "Minha culpa é muito pesada para suportá-la.

14 - Vê! Hoje tu me banes do solo fértil, terei que ocultar-me longe de tua face e serei errante fugitivo sobre a terra: mas o primeiro que me encontrar me matará!

15 - Iahweh lhe respondeu: "Quem matar Caim será vingado sete vezes." E Iahweh colocou um sinal sobre Caim, a fim de que não fosse morto por quem o encontrasse.

16 - Caim se retirou da presença de Iahweh e foi morar na terra de Nod, a leste de Éden. ${ }^{9}$

Da violência coercitiva (estrutural) surge uma violência sangrenta, da qual o jovem Abel é a primeira vítima. A maldição de Deus sobre Caim vai acompanhada de mais uma expulsão, que faz de Caim um desterrado, errante e apátrida, embora acima de tudo o transforme, mediante a proteção de um sinal, bastante diferente do que popularmente compre-

9 Bíblia de Jerusalém, p. 39. 
endemos como o sinal de Caim, em um homo sacer no sentido de Giorgio Agamben; aquele a quem se pode matar, embora não se deva sacrificar ${ }^{10}$. No entanto, a espiral da violência segue girando: a história humana começou e sob o signo de Caim se tornou uma história de desterrados, errantes e apátridas ao leste do Jardim do Éden, contudo, não fora do conhecimento.

Pois bem, a partir da perspectiva adotada aqui, é crucial que, a partir do fratricídio, se apresente por sua vez e com toda a sua potência, o questionamento sobre a convivência em paz e com a diferença. A intervenção divina - a saber: depois do fratricídio - não tem nenhuma solução preparada para o problema da violência: somente combina mais uma expulsão com mais uma proibição, onde ambas inauguram uma história de futuras proibições e expulsões; exílios e diásporas, que fora do Paraíso e antes da chegada do Messias não deixam germinar nenhuma esperança de encontrar um caminho de retorno da expulsão ao Jardim, de retorno à verdadeira pátria da humanidade. Deus não tem nenhum remédio pronto contra a violência, ao contrário, a segue alimentando. Porém, é assim também que ao ser humano, a quem não se separou do conhecimento, foi concedida, como resposta ao assassinato e à violência, a possibilidade de desenvolver um saber específico - seu saberconviver (ZusammenLebensWissen) - e de inventar formas para sua transmissão e atualização. Embora seja inegável que o ser humano desenvolve cada vez mais técnicas para a violência e o assassinato, também é verdade que se deu a ele a possibilidade de buscar formas de convívio e de dispor de um acervo de conhecimento para isso. Muito mais tarde esse depósito interativo e vívido, onde os tempos, os espaços e as culturas se entrecruzam, será descrito com aquele nome que foi sempre, literalmente, precário: literatura. A história da criação como história humana é, sem a história da literatura, sem o ato de contar e seu reflexo sobre a comunidade de ouvintes e leitores, simplesmente inconcebível.

Desde o princípio da história humana como história da expulsão, o ser humano não apenas empregou técnicas cada vez mais sofisticadas para a violência, como também transmitiu, através dos séculos, técnicas de conservação e uso de seu saberconviver. Nesse sentido, se distinguem nas passagens citadas do Gênesis, constelações da violência que, sob o signo da expulsão, da perseguição e do assassinato, colocam em perigo extremo a convivência entre Deus e os seres humanos, mas também entre os seres humanos e os animais - Deus amaldiçoa a serpente e a transforma assim em uma eterna inimiga dos seres humanos. A partir desta visão, é possível descrever o progresso da história da humanidade como uma ameaça extrema sobre este saberconviver, o que de certa forma foi um dom no início, mas que no transcorrer da história teve que ser organizado - e nisto o signo de Caim é paradigmático - mediante contínuas proibições, normas legais e sistemas de signos. $\mathrm{O}$ ato de narrar, ou aquilo que hoje chamamos de literatura - em um sentido mais geral e mais amplo que o de belas letras - enquanto forma condensada de expressão cultural e artística, na qual se relacionam as épocas da humanidade e as diferentes culturas, sem dúvidas, conta como uma das formas mais importantes desses sistemas de signos que estão dispostos para a transmissão e transformação do saberconviver.

A história da expulsão do paraíso de Adão e Eva nos confronta - e este é um conhe-

10 Ver Agamben, Giorgio: Homo sacer. Die souveräne Macht und das nackte Leben. Aus dem Italienischen von Hubert Thüring. Frankfurt am Main: Suhrkamp 2002, p. 18. 
cimento doloroso - com o fato de que a história está baseada fundamentalmente em mecanismos de exclusão sob o signo da violência ou, em outras palavras, do incremento da violência. De fato, nessa narrativa sobre a criação do mundo e do universo, os mecanismos de integração parecem retirar-se da esfera humana, já que a própria reintegração ao Paraíso terrenal será fundamental e violentamente negada tanto aos primeiros seres humanos como a sua descendência. O que resta então aos humanos? O que há além de sua vida nua e de sua sobrevivência?

A partir de uma performance de Vanessa Beecroft, realizada em abril de 2005 na Galeria Nacional de Berlim, Giorgio Agamben, por outra perspectiva - ainda que não por isso deixe de complementar a nossa - tentou refletir, com a maior precisão possível até agora, sobre o "descobrimento" da nudez através de Adão e Eva, ao reconhecer, por um lado, que a nudez - a que não existia neste sentido antes do pecado original - se deduz do fato de não estar vestido ${ }^{11} \mathrm{e}$, por outro lado, ao destacar com inteligência que "a nudez em nossa cultura não é um estado, mas sim um acontecimento" 12 . Se quiséssemos situar essa perspectiva que Agamben seguirá até a reprodução do corpo feminino em revistas pornográficas, com as questões aqui pesquisadas, faltaria determinar que o conhecimento que experimentam Adão e Eva de sua nudez, como consequência da incorporação de um fruto da árvore do conhecimento - existe Apple antes de Macintosh -, não apenas abre seus olhos e transforma seus corpos, como também usurpa do casal humano originário sua (invisível) vestimenta de Graça, descobrindo-os violentamente. As vestimentas de pele entregues por Deus revelam precisamente isso, através de seu ocultamento ostensivo.

Deste modo, aos expulsos do Paraíso, ao serem excluídos daquele espaço vital privilegiado - onde não por acaso se encontra a vida eterna prometida (e que remete intertextualmente à Epopeia de Gilgamesh) na árvore da vida ${ }^{13}$-, se imprime neles ao mesmo tempo uma simbologia do corpo humano diferente, com a qual o corpo dos desterrados - como acontecerá depois com Caim - é sinalizado e designado. Exposto ante seus próprios olhares e trocas, os assim designados ficam marcados por uma violência, que se executará tanto neles como em seus filhos e nos filhos de seus filhos. O Gênesis 3, 7 oferece, de certo modo, a cena primordial do nascimento do olhar cognoscente e de um processo civilizador derivado dele. "Então abriram-se os olhos dos dois e perceberam que estavam nus; entrelaçaram folhas de figueira e se cingiram".

Nessa passagem, sobre a primeira proteção do olhar, aparece o momento da expulsão da roupagem de pele, com a qual, ao mesmo tempo o animal se torna vítima dos seres humanos e com isso uma convivência de paz entre homem e animal - assim também é possível compreender essa cena de vestimenta forçada - encontra seu final definitivo. Da mesma forma como ocorre no caso de Caim, o signo outorgado por Deus protege, mas também transforma aos que designa como sujeitos marcados por seu destino, pela privação e perda

11 Agamben, Giorgio: Nacktheiten. Aus dem Italienischen von Andreas Hiepko. Frankfurt am Main: S. Fischer 2010, p. 100 .

12 Ibid. p. 110.

13 Ver sobre isso: Westermann, Claus: Biblischer Kommentar. Altes Testament. Genesis. Neukirchen: Neukirchener Verlag 1966, p. 291; sobre a ambivalência do acesso à árvore da vida: Schmid, Konrad: Literaturgeschichte des Alten Testaments.

Eine Einführung. Darmstadt: Wissenschaftliche Buchgesellschaft 2008, p. 136. 
de uma convivência paradisíaca. Eles sabem que foram desterrados para sempre do Jardim do Conhecimento, para buscar conscientemente, mais de uma vez e mediante novas formas, uma aproximação a este Jardim. O conhecimento reflexivo sempre inclui também o conhecimento sobre a perda do conhecimento. Ao mesmo tempo, é o saber referente à própria condição de renegados que faz desta renegação o motor de todo saber e de todo querer-saber. De tal modo, o Jardim do Conhecimento permanece onipresente e, ainda assim, não deixa de ser, em um sentido onisciente, inalcançável.

A história da criação toma sua prepotência (Gewalt) narrativa - e aqui isso pode ser formulado como hipótese - da violência que narra, violência que enquanto narrativa, leva ao mesmo tempo de um lugar estático, o Paraíso (terrenal), em direção a um movimento errante e apátrida e com isso, de uma história espacial (que se fixa no espaço) a uma história móvel (que se fixa no movimento). Podemos conceber a história humana, a partir desse momento, de outra maneira que não seja a de uma história em movimento? Mesmo que estes movimentos busquem sempre localizar-se ou domiciliar-se: o Gênesis deixa claro que a história humana se situa sob o signo da violência e de um movimento interminável, e cuja redução a uma história espacial seria inadmissível. A passagem da história da criação à história da humanidade é um processo vetorial que sempre traduz a perda padecida e a violência experimentada em novas figuras móveis da expulsão, do estrangeiro, do fugitivo, do nômade, do migrante, do pária.

Nesse sentido móvel da história - e as literaturas do mundo, a partir de suas diversas origens, sabem informar-nos sobre isso em seus múltiplos idiomas - é possível dizer justificadamente, junto ao pesquisador de migrações Klaus Bade, que: 'O 'Homo migrans' existe desde que o "Homo sapiens" existe; a transumância corresponde à conditio humana tanto quanto o nascimento, a procriação, a doença e a morte." ${ }^{14}$ Assim, basicamente dá no mesmo que os seres humanos sejam os que se movam sobre as fronteiras ou sejam as fronteiras as que se movam sobre os seres humanos: as ideias territoriais ou territorializantes com proveniência histórico-espacial permitem vez ou outra reconhecer seus esforços para filtrar e isolar a dimensão histórico-móvel e vetorial da história como narrativa, para tentar construir com a ajuda de ideias estáticas, novos lugares da promessa ou da perda, da abundância ou da queda.

Mas também me parece que nesse sentido a história da criação nos outorga no caminho, na heterotopia absoluta do Paraíso - aquele lugar que jamais poderá ser novamente alcançado - a capacidade de reconhecer simbolicamente uma construção que não serve para nenhum outro lugar, a leste do Éden ou ao redor do globo. No Gênesis, a abstração e separação desta heterotopia já estão implicadas: como se poderia pensar um mundo, cujo único lugar par excellance é por definição inacessível, de outra forma que não fosse vetorial?

Espero que as reflexões anteriores tenham demonstrado com suficiente clareza, que esta não é uma projeção livre de tensões e violência. Seja mediante a violence de contrainte ou a violence sanglante, a história é impulsionada mais de uma vez pelas formas mais diversas da violência, frente às quais, obviamente, não estamos nem indefesos nem entregues. As

14 Bade, Klaus: Europa in Bewegung. Migration vom späten 18. Jahrhundert bis zur Gegenwart. München: Verlag C.H. Beck 2000, p. 11. 
literaturas do mundo implicam em suas narrativas, em suas gnoses, um saber condensado tanto sobre as normas quanto das formas de um saberconviver, que sempre teve que enfrentar os desafios da violência. Elas constituem um Jardim do Conhecimento, que através das culturas, dos milênios e dos séculos permite acessar (e sempre transformar) um conhecimento, que sabe criar, a partir da carga (Last) de suas perdas passadas, como também das formas dos artifícios (List) atuais, o desejo (Lust) do que está por vir e para o porvir.

\section{CAMINHOS PARA URUK, CAMINHOS PARA ÍTACA}

De que linhas da tradição e de que meios discursivos e narrativos dispõe a literatura ocidental, quando deseja nos contar o mundo e nos narrar sobre a totalidade do universo? No capítulo dedicado à "Cicatriz de Ulisses", o primeiro de seu livro Mímeses: a representação da realidade na literatura ocidental, escrito em seu exílio em Istambul entre maio de 1942 e abril de 1945, logo após sua fuga de Marburg, o romanista Erich Auerbach se propôs ao mesmo tempo a contrastar e comparar o mundo de Homero com o mundo da Bíblia. O "texto narrativo bíblico" (biblische Erzählungstext), segundo a inteligente expressão de Auerbach, não tenta

[n]os fazer esquecer nossa própria realidade durante algumas horas, como Homero, mas quer subjugá-la; nós devemos acomodar nossa própria vida a seu mundo, e nos sentirmos parte de sua construção histórico-universal, o que se faz cada vez mais difícil, à medida que o mundo em que vivemos se afasta cada vez mais das Escrituras Sagradas [...] Quando isso já não pode ser feito, por causa de uma mudança de ambiente muito violenta, ou pelo despertar da consciência crítica, a pretensão de domínio se encontra em perigo [...]. Os poemas homéricos proporcionam uma relação de acontecimentos bem determinada, delimitada em tempo e lugar; antes, junto e depois dela são perfeitamente pensáveis outras cadeias de acontecimentos, sem conflito nem dificuldade alguma. Ao contrário, o Antigo Testamento nos oferece uma história universal; começa com o início dos tempos, com a criação do mundo, e quer terminar com o fim dos séculos, ao se cumprirem as profecias. Todo o restante que ocorra no mundo, só pode ser concebido como um elo desta cadeia. [...] $\left(1996\right.$, p. 21-22) ${ }^{15}$

O fato de que Erich Auerbach nunca tenha entendido a Romanística como uma área de estudo com fronteiras sólidas e que já nestas reflexões estivesse em busca das marcas de uma "Filologia da Literatura mundial"16, que compreendia o mundo homérico e vetero-

15 Auerbach, Erich: Mímesis. La representación de la realidad en la literatura occidental. Tr. de I. Villanueva y E. Ímaz. México D.F.: Fondo de Cultura Económica ${ }^{6} 1996$, p. 21-22.

16 Cfr. Erich Auerbach, "Philologie der Weltliteratur". Em: Weltliteratur. Festgabe für Fritz Strich. Bern 1952, p. 39-50; reeditado em Auerbach, Erich: Gesammelte Aufsätze zur romanischen Philologie. Herausgegeben von Fritz Schalk und Gustav Konrad. Bern - München: Francke Verlag 1967, s. 301-310. Sobre isso cfr. também Ette, Ottmar: "Erich Auerbach oder Die Aufgabe der Philologie”. Em: Estelmann, Frank / Krügel, Pierre / Müller, Olaf (Hg.): Traditionen der Entgrenzung. Beiträge zur romanistischen Wissenschaftsgeschichte. Frankfurt am Main - Berlin - New York: Peter Lang 2003, p. 21-42. 
testamentário como os dois pontos de partida e referência fundamentais, cujos campos de força permeavam a representação da realidade na literatura ocidental até o presente, levou o filólogo à percepção de uma estrutura que à primeira vista parece ser paradoxal:

O Antigo Testamento é em sua composição incomparavelmente menos unitário que os poemas homéricos; é, mais obviamente que eles, uma reunião de peças soltas; no entanto, todas essas peças entram em uma conexão histórico-universal, de uma interpretação da história universal (1996, p. 22). ${ }^{17}$

Por consequência, à estritamente limitada fragmentariedade espaço-temporal da Ilíada e da Odisseia, corresponde uma maior unidade narrativa, enquanto, ao contrário, a "perspectiva religiosa e histórico-universal" 18 uniforme do Antigo Testamento repercute no nível textual em uma fragmentária acumulação de peças soltas. Impulsiona até hoje, então, uma motricidade bipolar à literatura ocidental?

A essa interpretação contrastiva de Erich Auerbach, a que hoje poderíamos aderir com segurança, é necessário agregar, obviamente, que a característica de ser uma entidade de peças soltas e reunidas não resulta tão gravitante no momento em que, ao invés de nos ocuparmos da construção geral do Antigo Testamento, nos concentramos - como já dissemos - em episódios ou elementos específicos da história da criação. Sem que isso destrua a divisão estabelecida por Auerbach, é aqui onde a potência narrativa, que é em grande parte independente das consideráveis transformações que efetuam seus leitores em seu mundo vital, recorre por completo ao meio de uma representação unitária do mundo.

Isso, há que apontar, possibilita ou garante nas línguas, nas culturas e nos tempos mais dissímeis, a transferibilidade e a tradutibilidade de uma narrativa que precisamente, como aquela sobre a expulsão dos primeiros seres humanos do paraíso, está impregnada de uma grande unidade (e prepotência) narrativa. A história da expulsão de Adão e Eva funciona como uma mise em abyme de toda a história da criação e da salvação - uma coisa que no ocidente é, em grande parte, independente das fronteiras idiomáticas ou geoculturais, como nos demonstram impressionantemente as obras de Dante Aliguieri e Milton até Proust e Lezama Lima. Não foi a busca de Cristóvão Colombo do Paraíso terreno e sua alienável convicção de encontrar, ao estar frente à foz do Orinoco, ante um dos afluentes deste paraíso, um dos movimentos essenciais da história do descobrimento e da expansão europeia? ${ }^{19}$

A dialética do fragmento e da totalidade ${ }^{20}$, estudada há muito tempo, se completa nesta paisagem inicial de Mímeses de Auerbach com uma não menos potente correlação entre o que se poderia formular como um exercício de limitação espaço-temporal e uma dissolução espaço-temporal dos limites, tanto do mundo histórico alicerçado no mundo da vida,

17 Auerbach, Erich: Mímesis, p. 22.

18 Ibid.

19 Sobre a extensa opinião de que o acesso ao Paraíso só seria possível através do Leste, consultar Scharbert, Josef: Die neue Echter Bibel, p. 62.

20 Cfr. entre outros Dällenbach, Lucien / Nibbrig, Christiaan L. Hart (Hg.): Fragment und Totalität. Frankfurt am Main: Suhrkamp 1984. 
como da história do mundo alicerçada na religião. Para nosso problema, é revelador que a dimensão histórico-universal não somente se vincule com as pretensões do poder e com as prerrogativas de interpretação absoluta que buscam relacionar inclusive os fenômenos mais distantes no tempo e no espaço com a própria história (sagrada), mas além disso, que esta dimensão se desdobre a partir de uma abstração das condições espaço-temporais concretas. Tal abstração provê a transferibilidade e assegura o fluxo de saberes transgeracionais, inclusive quando se produzem profundas transformações ou agudas rupturas dentro de cada contexto vital.

A dupla tradição da representação da realidade na literatura ocidental, que Erich Auerbach colocou em evidência, pode ser confirmada também em sua potência se destacamos desde o início - e, à primeira vista, contra a tese que subjaz a Mímeses - o entrelaçamento íntimo da interpretação religiosa do mundo com a secular. O melhor exemplo de uma configuração textual como essa o dá sem dúvidas a Epopeia de Gilgamesh, cujas tábuas de barro remontam à Mesopotâmia do último terço do segundo milênio antes de Cristo, mas cujas versões iniciais remetem a ainda antes: ao terceiro milênio antes de $\mathrm{Cristo}^{21}$. Nessa epopeia, a dimensão de uma convivência cambiante entre os deuses, os seres humanos e os animais, dentro de um processo histórico-humano da civilização, adquire uma grande importância. ${ }^{22}$

Assim, é necessário levar em conta que no centro da Epopeia de Gilgamesh não se encontra um espaço ou uma paisagem paradisíaca, mas uma paisagem urbana, tal qual se desenvolveu exemplarmente em sua particularidade na Mesopotâmia. De tal modo, como microcosmos no desenho de um universo completo, a grande cidade de Uruk é na realidade a protagonista desta epopeia: dela saem todos os caminhos de Gilgamesh, para ela levam todos os caminhos dos heróis assim como dos deuses. Ela se situa no centro de diversos movimentos que saem dela e que levam a ela e constituem um padrão esteliforme que está presente em cada uma das tábuas de barro. A urbanidade e a literatura estão vinculadas intimamente entre si desde os tempos mais remotos.

A prerrogativa daquilo que hoje designamos como literatura, sobre a compreensão de uma totalidade de toda a criação e de tudo que foi, tanto quanto sobre o desdobramento de uma consciência mundial alicerçada nesta compreensão, se manifesta já nas primeiras tábuas de barro dessa epopeia, que esboçam os movimentos esteliformes que cruzam os espaços e os tempos em sua profundidade.

Aquele que viu a profundidade, os confins da terra,

que conheceu o oculto, aquele que tudo soube -

Gilgamesh, o que viu a profundidade, os confins da terra,

que conheceu o oculto, aquele que tudo soube -

21 Sobre isso consultar Maul, Stefan M.: “Einleitung”. En: Das Gilgamesch-Epos. Neu übersetzt und kommentiert von Stefan M. Maul. München: C.H. Beck 2005, p. 13 s.

22 A esse respeito ver: Ette, Ottmar: ZusammenLebensWissen, p. 34-36. 
familiares são para ele os assentos dos deuses todos

Sabedoria total obteve de cada uma das coisas

Contemplou os segredos e desvendou os mistérios,

trouxe notícias do tempo antes do Dilúvio. ${ }^{23}$

Nessas antiguíssimas tábuas de barro, a literatura é proposta como uma consciência de mundo localizada e em constante movimento, cujo lugar de referência e de passagem é sempre, naturalmente, o espaço (de trânsito) urbano na Mesopotâmia. No início, ele é intercalado em sua pura espacialidade, em sua impressionante extensão espacial, cada vez com orgulho evidente (e mais uma última vez, no final da epopeia), onde a engrenagem da urbanidade, a natureza e a natureza cultivada pelos seres humanos, tanto quanto sua dimensão transcendental, estão marcadas com extrema clareza. Uruk é o microcosmos. O espaço urbano - não nos esqueçamos - é por sua vez o espaço da literatura:

Trezentos hectares completos de cidade.

Trezentos hectares completos de jardim

Trezentos hectares completos de várzea

Cento e cinquenta hectares do Templo de Ishtar

Mil e cinquenta hectares, isso é Uruk, essas são suas medidas! $!^{24}$

O espaço estendido aqui é, sem dúvida alguma, em um sentido histórico-móvel, um espaço de trânsitos; Uruk se configura através das viagens e excursões de Gilgamesh, que cruzam sempre de novo e com isso a conectam com os confins mais distantes da terra. A cidade é uma ilha no arquipélago de suas relações, que envolvem o mundo inteiro - urbi et orbi. A cidade resplandecente e amuralhada é o reino dos seres humanos e o reino dos signos: especialmente de sua literatura, reunida a partir de tijolos e pedaços de barro.

Assim, a Epopeia de Gilgamesh inaugura, junto a todos os seus precursores ${ }^{25}$ e todas as suas potentes modelações histórico-literárias e histórico-religiosas, uma longa tradição

23 (N.T.) Tradução livre realizada a partir da versão espanhola do texto. Os versos em alemão são os seguintes: „Der, der die Tiefe sah, die Grundfeste des Landes, / der das Verborgene kannte, der, dem alles bewußt - / Gilgamesch, der die Tiefe sah, die Grundfeste des Landes, / der das Verborgene kannte, der, dem alles bewußt - // vertraut sind ihm die Göttersit$z e$ allesamt. / Allumfassende Weisheit erwarb er in jeglichen Dingen. / Er sah das Geheime und deckte auf das Verhüllte, / er brachte Kunde von der Zeit vor der Flut.“ Das Gilgamesch-Epos, p. 46.

24 Das Gilgamesch-Epos, p. 46.

25 Em relação às reflexões genealógicas da epopeia cfr. Maul, Stefan M.: “Einleitung”. En: Das Gilgamesch-Epos, pp. 9-18. 
artística, dentro da qual, em uma forma literária extensa, se entrelaçam com frequência a representação do universo com a da cidade e se traduz a relação entre o microcosmos e o macrocosmos. Assim, se inscrevem respectivamente tanto a cidade como a literatura - que a partir de todas as frentes devem encarar o desafio de representar o infinito mediante uma forma finita e delimitada - no lado do microcosmos, onde os seres humanos finitos, que foram criados finitos, adquirem sua própria forma e, ao mesmo tempo, apontam fractalmente em direção a sua descendência. Jardim e templo não são por acaso partes da cidade?

Para o desfecho da Epopeia de Gilgamesh, o herói também deve se conformar com essa finitude - ou seja, conseguir também acesso aos frutos da árvore da vida - , Gilgamesh volta a Uruk: "Depois de trinta quilômetros partiram o pão / depois de cinquenta quilômetros pararam para pernoitar / mas então chegaram a Uruk, a amuralhada." ${ }^{26}$ E pouco antes de que a décima primeira e última tábua de barro termine, com as mesmas palavras que já na primeira retratavam a cidade de Uruk, se fecha o círculo para o herói Gilgamesh, que volta das viagens ao redor do globo para sua cidade; um regresso a casa, que como figura de movimento hermenêutico não apenas fecha o círculo da narrativa, mas também lhe outorga sentido (seu polissêmico e tão fascinante sentido particular [Eigen-Sinn]) ao movimento completo da epopeia.

Com a culminância vetorial do círculo se fecha e se abre ao mesmo tempo o ciclo de uma vida. Na qual a sempre precária dotação "total” de sentido só pode se apresentar realizada e marcada a partir de seu fim ${ }^{27}$. No retorno à cidade protegida por muralhas gigantes, uma busca por conhecimento encontra sua conclusão. Isso deixa evidente que Gilgamesh, "o que viu a profundidade, os confins da terra, / que conheceu o oculto, aquele que tudo soube" ${ }^{28}$, retorna profundamente transformado à sua cidade. Agora sabe que não pode participar da imortalidade e, de fato, talvez suspeite que a gigantesca construção defensiva da cidade de Uruk, "obra de tijolos" ${ }^{29}$ que ele inspecionou mais uma vez, não será capaz de resistir a todos os embates futuros e desaparecerá.

O momento de retorno, um tópos da literatura de viagem altamente semantizado ${ }^{30}$, é por sua vez o lugar de um conhecimento fundamental, embora doloroso: a saber, o conhecimento de que a passagem do tempo impede de se regressar ao mesmo, ao idêntico. Por mais que a cidade de Uruk se apresente como se jamais tivesse mudado, a volta para casa é sempre o retorno a uma outridade que nos seduz com o brilho do familiar, do mesmo; e justamente por isso, em toda evocação da "pátria", da "terra natal" e da própria "origem", é impossível esconder que quem retorna não é mais aquele que era quando saiu de sua casa. O regresso à pátria é simultaneamente o retorno ao familiar e ao outro.

26 Das Gilgamesch-Epos, p. 152.

27 Sobre a figura móvil do círculo, ver: Ette, Ottmar: Literatur in Bewegung. Raum und Dynamik grenzüberschreitenden Schreibens in Europa und Amerika. Weilerswist: Velbrück Wissenschaft 2001, p. 21-84. Versão em espanhol: Literatura en movimiento: Espacio y dinámica de una escritura transgresora de fronteras entre Europa y América. Traducción de Rosa María S. de Maihold. Madrid: Consejo Superior de Investigaciones Científicas 2008.

28 Das Gilgamesch-Epos, p. 46.

29 Ibid., p. 152.

30 Ver: Ette, Ottmar: Literatur in Bewegung, pp. 60-62. 
Me parece que Erich Auerbach, o migrante, manifesta plena consciência desse fato em sua escrita crítica - e teórico-literária. Não por coincidência, Mímeses, sua obra prima escrita no exílio, começa com a cena de regresso de Ulisses, que é reconhecido por sua criada Euricléia por estar marcado, no duplo sentido da palavra, por sua cicatriz. É muito provável que Auerbach, que marcado pelo exílio, não regressou de Istambul a Marburg, mas migrou mais uma vez, então aos Estados Unidos, pode escolher com premeditação aquele cenário em que a anagnórise, o reconhecimento de Ulisses por sua cicatriz, nutre a esperança de poder ainda regressar a esse lugar do qual um dia, e contra a vontade, teve que sair. Ao contrário do "texto narrativo bíblico" 31 , nessa segunda ramificação da tradição narrativa do ocidente, se mantem a possibilidade e factibilidade de um retorno, no sentido espacial de uma Return Migration ${ }^{32}$.

A renúncia de Auerbach a qualquer tipo de prólogo ou introdução que pudesse deixar explícita desde o início sua própria situação de exílio, seu próprio lugar de escrita, faz com que toda a atenção do leitor recaia sobre as primeiras linhas do primeiro capítulo, sobre o incipit imediato. De fato, o leitor é evocado diretamente no conhecido começo de Mímeses: Os leitores da Odisseia recordarão a emocionante e bem preparada cena do Canto XIX, na qual a velha ama Euricleia reconhece Ulisses, de quem havia sido ama de leite, pela cicatriz na coxa. ${ }^{33}$

Sem nenhuma dúvida, sob o movimento do Ulisses que regressa, se esconde um autorretrato daquele imigrante judeu que teve que abandonar a Alemanha nacional-socialista para salvar sua vida nua. Na ambígua figura de Ulisses se incorpora a experiência do exílio, do errante, em um espaço fractal e fraturado em múltiplos níveis - como também um pedacinho de esperança de regressar, de voltar a ser reconhecido, cujo desencadeante é precisamente a ferida, a "cicatriz de Ulisses". No entanto, não menos impressionante deveria ser o fato de que nessas referências da expulsão e do desterro vive também a saudade de uma comunidade, que já na primeira linha e pela primeira vez se denomina comunidade de leitores e que no final do breve epílogo do livro, se evocará novamente:

Com isto disse tudo o que creio que devo dizer ao leitor. Só falta encontrá-lo, ao leitor.

Tomara que minha pesquisa chegue tanto aos meus antigos amigos sobreviventes, como a todos aqueles leitores a quem se direciona, e possa contribuir com a

31 Auerbach, Erich: Mímesis, p. 18.

32 Francesco Cerase diferencia entre quatro formas de Return Migration: 1. Por falta de sucesso; 2 como retorno "conservador"; 3. Como retorno "inovador"; 4. Retorno para passar o último período da vida na antiga terra natal. Ver: Cerase, Francesco: "Nostalgia or Disenchantment: Considerations on Return Migration”. Em: Tomasi, Silvano M. (Hg.): The Italian Experience in the United States. Staten Island, N.Y.: Center for Migration Studies 1970, p. 217-238. Ver também: Glettler, Monika: “Zur Problematik der Rückwanderung aus den USA nach Südosteuropa vor dem Ersten Weltkrieg”. Em: Heumos, Peter (Hg.): Heimat und Exil, Emigration und Rückwanderung, Vertreibung und Integration in der Geschichte der Tschechoslowakei. Vorträge der Tagungen des Collegium Carolinum in Bad Wiessee. München: Oldenbourg 2001, p. 85-98; também Tsuda, Takeyuki (Hg.): Diasporic Homecomings. Ethnic Return Migration in Comparative Perspective. Stanford: Stanford University Press 2009.

33 Auerbach, Erich: Mimesis, p. 9. 
reunião dos que conservaram limpidamente o amor por nossa história ocidental! $(1996, \text { p. 525) })^{34}$

En filigrane, mas justamente por isso com maior ênfase, Erich Auerbach inscreve aqui as catástrofes da Segunda Guerra Mundial e da Shoah em um texto que encontrará novamente a comunidade de leitores sobreviventes, mas que também inventará uma nova comunidade de leitores. O desespero diante de uma história de extermínio, que para Auerbach se transformará na causa de sua própria vida e escrita, não apenas torna audível nessa passagem o grito que se esconde na escrita (Schrei im Schreiben), mas também não nos permite fechar os olhos para o fato de que esta comunidade de leitores pensada por Auerbach não está nem fixada territorialmente nem situada unicamente na Alemanha.

Deste modo, se abre em Auerbach o trabalho sobre o mito e no mito ${ }^{35}$ de Ulisses que retorna, ainda que não se baseie em um mito de retorno à Alemanha. Auerbach sabia certamente que um regresso como esse o levaria a uma terra que reconheceria as cicatrizes do passado tão bem como Euricléia, mas que diante da contemplação do que regressa não irromperia "em um sobressalto alegre" nem em espontâneo “júbilo" ${ }^{36}$. Finalmente, Erich Auerbach se decidiu pela reimigração, embora não em termos de um "regresso" a Marburg, fosse esse do tipo que fosse.

Nesse ponto se perfila com clareza uma relação com o poeta neo-helênico nascido em Alexandria, Konstantinos Kavafis, que em seu famoso poema "Ítaca", mostra um trabalho sobre o mito, que problematiza a figura de compreensão e de movimento de retorno com uma radical reinterpretação. Assim Kavafis, já nos primeiros versos, coloca seu leitor no caminho "Quando saíres na viagem para Ítaca / deseja que o caminho seja longo, / pleno de aventuras, pleno de conhecimento". ${ }^{37}$ E assim, neste poema de Kavafis do ano 1911, quem regressa embarca em um caminho que dura longos anos até que Ulisses, até que o fugitivo e o forasteiro envelhecido, já familiarizado com muitos portos e enriquecido com muitas experiências, chega a Ítaca. No entanto, como se expõe nas últimas estrofes, seu regresso não é exatamente um regresso à pátria:

Ítaca te deu uma bela viagem.

Sem ela não terias saído ao caminho.

Outras coisas não têm mais para dar-te

E se pobre a encontras, Ítaca não te enganou

34 Ibid., p. 525.

35 Ver: Blumenberg, Hans: Arbeit am Mythos. Frankfurt am Main: suhrkamp 41986.

36 Auerbach, Erich: Mímesis, p. 9.

37 Kavafis, Konstantinos: “Ítaca”. En: Castillo Didier, Miguel. Kavafis íntegro. Traducción, edición, notas y ensayo introductorio de Miguel Castillo Didier. Santiago de Chile: Quid ediciones; Centro de Estudios Griegos, Bizantinos y Neohelénicos “Fotios Mallero", Universidad de Chile ²003, pp. 
Sábio, assim como chegaste a ser, com experiência tanta

Já terás compreendido o que as Ítacas significam. ${ }^{38}$

Não como chegada, mas como propósito, não como regresso, mas como movimento se mitificam nesse poema todas as Ítacas que representam a abundância e a realização, e que somente não nos iludirão ou enganarão, se as seguirmos contemplando em um movimento sem chegada e sem retorno como o horizonte dos viajantes. O retorno será sempre e unicamente um retorno ao desconhecimento, ao que se tornou desconhecido e miserável, onde teríamos que haver concluído nossas vidas.

Finalmente, não será o retorno depois de uma longa viagem, de uma longa migração, um ilusório engano seguido bem de perto pela desilusão? No texto fragmentário Beginnlosigkeit (1992) de Botho Strauß, constantemente marcado por "desvios, imitações, repetições, correspondências" 39 , esta figura é colocada na cena em referência ao poema "Ritorno" (Retorno) do poeta italiano Giorgio Caproni no sentido de um retorno ao que nunca esteve:

Estou de volta alí

Onde nunca estive

Nada do que era mudou

Sobre a mesa (sobre a toalha

xadrez) encontrei

o vaso que nunca

se encheu. Tudo

permanece ainda, tal qual,

como nunca o deixei. ${ }^{40}$

Devemos estar alertas, então, quando nos aproximamos do padrão de movimento de "retorno" ou da assim chamada Return Migration: através dos séculos, as culturas escritas em diferentes tempos e espaços criaram advertências que deveriam nos sensibilizar sobre o fato de que o retorno à pátria, em seu sentido mais forte, só é possível se conseguirmos su-

38 Ibid.

39 Strauß, Botho: Beginnlosigkeit. Reflexionen über Fleck und Linie. München - Wien: Carl Hanser Verlag 1992, p. 19.

40 Ibid., p. 18 f. O poema original el italiano, do ano 1971, se encontra em Caproni, Giorgio: Poesie 1932 - 1986. Milão:

Garzanti 1989, p. 392. 
primir toda transformação e todo transcorrer do tempo, para evitar que o regresso nos leve a uma terra ou a um lugar que desta forma - simplesmente por nossa nova condição como o que regressa - jamais vivenciamos. A literatura sabe disso desde todos os seus inícios: ela é a escrita e a leitura depois da expulsão do Paraíso.

Consequentemente, fica claro que não é necessário, como faz Botho Strauß, adotar uma substituição do movimento contínuo e direcionado de retorno em um movimento descontínuo e fraturado, que também poderíamos descrever como "um padrão de movimentos, de transformações inconstantes e errantes" ${ }^{41}$; um pouco como acontece com os movimentos errantes e apátridas que Caim no Gênesis - a primeira narrativa migrante - deve arrastar pela terra junto a sua miséria. Mas apesar disso, não deixa de ser difícil tornar visível a figura móvel do retorno, cuja estrutura circular é absolutamente convincente, como uma figura contraditória - principalmente em um país em que o conceito de "reunificação" deve permanecer impassível para aquilo que, deste modo, nessas fronteiras e nessa constituição, jamais existiu. Não é possível suspeitar neste ponto, e com boas razões, de um ideologema dirigido por certos interesses particulares?

\section{CAMINHOS TEMPESTUOSOS DESDE O PARAÍSO}

Mas retornemos novamente a Ulisses, esta figura móvel e cognoscente tão fascinante, que atravessa toda a literatura e filosofia ocidental. Já que no fim das contas Ulisses não se entregou à busca de qualquer forma de Paraíso terrenal, mas ao regresso à sua ilha natal, a Ítaca. Mesmo quando enfrenta de boa vontade, mais de uma vez, todo tipo de seduções, se expõe ao canto das sereias ou às tentações de Calipso, deseja em primeiro lugar - dito de forma simples - regressar à sua pátria depois da Guerra de Tróia. Um simples soldado que volta da guerra, ainda que, obviamente, não seja um soldado qualquer.

Não é coincidência que, quase ao mesmo tempo em que foram escritas as reflexões de Auerbach sobre $A$ representação da realidade na literatura ocidental, se escrevesse durante os anos 1941 e 1944 um livro, em que a figura cognoscente de Ulisses volta a aparecer, precisamente onde menos se esperaria. Se trata de um produto da emigração. A dialética do esclarecimento de Max Horkheimer e Theodor W. Adorno, com uma tiragem de quinhentos exemplares, foi repartida pelos autores "entre amigos" pela primeira vez em 1944, antes de que esses "Fragmentos filosóficos" aparecessem publicados como livro e com o título definitivo, em 1947 pela editora Querido, de migrantes de Amsterdã. Nestas páginas, e não apenas no primeiro excurso intitulado "Ulisses, ou mito e esclarecimento" ${ }^{42}$, Ulisses é quase onipresente. Como devemos entender isso? ${ }^{43}$

Segundo ambos os filósofos que, frente aos capangas do nazismo, escaparam por di-

41 Ibid., p. 128.

42 Horkheimer, Max / Adorno, Theodor W.: La dialéctica de la Ilustración: Fragmentos filosóficos (Obra Completa, Volúmen 3). Tradução de Joaquín Chamorro Mielke. Madrid: Akal 2007, p. 57. A citação da versão alemã se encontra na página 50 da edição já citada.

43 Uma exploração mais minuciosa dessa pergunta pode ser encontrada em: Ette, Ottmar: ZwischenWeltenSchreiben. Literaturen ohne festen Wohnsitz. Berlin: Kulturverlag Kadmos 2005, p. 31-37. 
ferentes caminhos ao exílio, a Odisseia "dá testemunho da dialética do esclarecimento" 44 e contém na separação da epopeia e do mito finalmente uma perda, porque o canto "[d]as viagens errantes de Ulisses" é "uma estilização nostálgica do que já não se deixa cantar", e na qual o "herói das aventuras se revela como protótipo do indivíduo burguês, cujo conceito se origina naquela autoafirmação unitária de que o herói aventureiro proporciona o modelo primitivo" 45 . Assim se revela - e aqui se encontram alguns paralelos não suspeitados com a interpretação de Auerbach sobre a epopeia homérica "o cosmos venerável do mundo homérico" como "produto da razão ordenadora que destrói o mito justamente em virtude da ordem racional na qual se reflete" 46 . Não era, pois, a Dialética do esclarecimento mais um trabalho sobre o mito do que uma destruição do mito em virtude da razão ordenadora?

Se Auerbach leu a Odisseia de maneira complementar e contrastiva com a Bíblia, do mesmo modo, Horkheimer e Adorno leram as aventuras de Ulisses sobre o fundo de uma lente histórico-filosófica, que estava disposta, não menos que as Escrituras Sagradas, em relação a "um contexto histórico-universal de interpretação da história universal"47. Como poderia haver sido de outra forma? Não caía todo o planeta e toda a humanidade, sob o signo de uma triunfal calamidade" ${ }^{48}$, com um ritmo vertiginoso "em uma nova forma de barbárie"? ${ }^{49}$

O registro explícito destes fragmentos dentro do trabalho continuado pelos emigrados alemães "apesar de Hitler" ${ }^{0}$, destaca sem dúvidas e de maneira evidente "a íntima aproximação dos conteúdos com o destino da humanidade, depois de duas guerras mundiais" ${ }^{1}$ : aqui lampeja uma identificação não apenas com os deslocados ou errantes, mas também com o astuto habitante da ilha. Na figura de Ulisses germina a esperança de que, na condição de errante ou deslocado, seja possível recuperar a própria (tanto individual como social) força de condução: "o náufrago temeroso antecipa o trabalho da bússola" e "sua impotência, à qual já não sobra nem um só palmo de mar por conhecer", tende por sua vez "a derrotar às potências" (Entmächtigung der Mächte) ${ }^{52}$.

Frente a esse contexto, Ulisses pode tornar-se uma figura impávida, que em seu regresso a Ítaca, a sua pátria, não se deixa desviar. Para Horkheimer e Adorno, em Ulisses se incorpora um "saber em que consiste sua identidade e que lhe permite sobreviver" 53 , já que

44 Horkheimer, Max / Adorno, Theodor W.: La dialéctica de la Ilustración: Fragmentos filosóficos (Obra Completa, Volúmen 3). Tradução de Joaquín Chamorro Mielke. Madrid: Akal 2007, p. 57. A citação da versão alemã se encontra na página 50 da edição já citada.

45 Ibid.

46 Ibid.

47 Auerbach, Erich: Mímesis, p. 19.

48 Horkheimer, Max / Adorno, Theodor W.: La dialéctica de la Ilustración, p. 19 (em alemão: p. 9).

49 Ibid., p. 11 (em alemão: p. 1).

50 Ibid. (em alemão p. 7).

51 Frenzel, Elisabeth: Stoffe der Weltliteratur. Ein Lexikon dichtungsgeschichtlicher Längsschnitte. 6., verbesserte und um ein Register erweiterte Auflage. Stuttgart: Alfred Kröner Verlag 1983, p. 564.

52 Horkheimer, Max / Adorno, Theodor W.: La dialéctica de la Ilustración, p. 60 (em alemão: p. 53).

53 Ibid. 
como o que "sobrevive sabendo", se apresenta por sua vez como aquele que "mais temerariamente se entrega à ameaça da morte, com a qual se endurece e fortalece para viver" ${ }^{24}$. $\mathrm{O}$ trabalho sobre o mito se transforma tanto em um trabalho sobre a própria autocompreensão, quanto sobre o modelo de movimento e de compreensão de um futuro retorno a uma terra, em que os homens frequentemente descrevem a si mesmos como fortes e firmes. A pátria não é, no entanto, o simples território, mas sim um motivo de movimento, já que: "Pátria é estar a salvo"55.

Somente no estar a salvo é que uma pátria volta a se fazer acessível, claro que não é, nem pode ser, um acesso a um estado originário, nem um regresso a uma procedência e uma pátria "original” no sentido tradicional da palavra. Só assim Ulisses pode, marcado e identificado por sua cicatriz, tornar-se o apátrida que regressa à pátria, a incorporação de uma dialética enclausurável da apatricidade, que - formulada paradoxalmente - no regresso recorda a impossibilidade de regresso. Do estar a salvo surge uma pátria que, como tal, nunca existiu antes.

Através da Dialética do esclarecimento está presente, como fio condutor, uma dialética da apatricidade que sob o signo de Ulisses está consciente do significado da navegação própria. Se a pátria é estar a salvo, então, salvar-se é um caminho e muitos caminhos para figurar a pátria, para invocá-la em uma figura (móvel), que se opõe a mais obstinada resistência a qualquer preconcepção de um simples retorno.

Nenhum dos contemporâneos de Auerbach, Horkheiner e Adorno, trouxe à luz essa problemática de maneira mais impressionante e precisa que Walter Benjamin; um desterrado pelas tormentas de seu tempo, cujo trajeto chegou ao fim na fronteira dos Pirineus. Benjamin escolheu para a história precisamente essa famosa figura, que paira sobre a humanidade ainda não "redimida" ${ }^{56}$. Com uma referência audaz a um "quadro de Klee que se chama Angelus Novus" 57 , propôs sua visão da história:

O anjo da história há de ter esse aspecto. Tem o rosto voltado ao passado. No que para nós aparece como uma cadeia de acontecimentos, ele vê uma só catástrofe, que incessantemente empilha ruína sobre ruína e as joga a seus pés. Bem, quisera demorar-se, despertar aos mortos e voltar a juntar o destruído. Mas uma tempestade sopra do paraíso, que se enredou em suas asas e é tão forte que o anjo já não pode dobrá-las. Essa tempestade o arrasta, irresistivelmente, para o futuro, ao que vira às costas, enquanto o acúmulo de ruínas cresce diante dele até o céu. Essa tempestade é o que chamamos progresso (1980, p. 694).$^{58}$

\footnotetext{
54 Ibid. (em alemão: p. 54).

55 Ibid., p. 90 (em alemão: p. 86).

56 Benjamin, Walter: “Tesis sobre el concepto de historia”. En: La dialéctica en suspenso: fragmentos sobre historia. Tradução, introdução e notas de Pablo Oyarzún Robles. Santiago de Chile: Lom edições; Universidade ARCIS 1996, p. 52. A citação em alemão se encontra em Benjamin, Walter: Über den Begriff der Geschichte. En: Gesammelte Schriften. Band I, 2. Herausgegeben von Rolf Tiedemann und Hermann Schweppenhäuser. Frankfurt am Main: Suhrkamp 1980, p. 694.
}

57 Ibid., p 53. (em alemão: p. 695).

58 Ibid., p. 53 s. (em alemão: p. 697 s.) 
Essa tempestade continua soprando a partir do Paraíso. Não por acaso, Stéphane Hessel, de noventa e três anos e sobrevivente de Buchenwald, propôs em seu ensaio de sucesso Indignez-vous! o anjo de Paul Klee e alguns elementos da interpretação de Walter Benjamin para reclamar a necessidade de lutar pelos valores que nos permitiram, no princípio, "estar orgulhosos de nossa sociedade" 59 . Enfrentada a tempestade, fica claro que a partir do leste do Éden e enredados no vento do progresso, é impensável um regresso ao Paraíso - pelo menos, até que renunciemos à ilusão de ainda poder alcançar a antiga pátria da humanidade, o Paraíso pessoal; ou seja, o da infância. Não será a interpretação de Walter Benjamin do "Angelus Novus", de Paul Klee, a prova mais clara para comprovar como a vetoricidade complexa que atravessa a história cultural do ocidente se concentra na ideia de Paraíso?

Entre os milhões que a tempestade da Segunda Guerra Mundial e da Shoah arrastou consigo, se soma também a poeta Emma Kann. Nascida em Frankfurt em 1914, no seio de uma família judaica, a jovem poeta teve que sair do exílio na Europa logo depois da tomada de poder em 1933. No caos da queda francesa e da reorganização dos campos de concentração, depois de mais ou menos quatro semanas internada no sul da França no campo de Gurs, foi liberada de forma "regulamentar", antes de que conseguisse, em 1942, enganar definitivamente a perseguição nazista e fugir para Havana por Casablanca ${ }^{60}$. A pátria como estar a salvo.

Devido à entrada de Cuba na guerra e os vistos de muitos refugiados terem perdido sua validade durante a viagem, Emma Kann foi internada em seguida em um campo de detenção próximo a Habana, antes que pudesse instalar-se na capital cubana. Ali se uniu à comunidade judaica, deu aulas de inglês, mas também precisou submeter-se a duas complicadas operações nos olhos ${ }^{61}$, que, no entanto, não puderam impedir sua posterior cegueira. Em março de 1945 se mudou para os Estados Unidos, onde viveu - principalmente em Nova York - até maio de 1981 e onde começou a escrever em inglês, altamente influenciada por suas relações pessoais com W.H. Auden. As décadas que transcorreram até seu regresso à Alemanha, Emma Kann descreveu, como era seu costume, em poucas palavras:

Em 1969 fiquei cega e passei em seguida minhas férias de verão em casas de veraneio na Áustria e depois na Suíça. Finalmente retornei em 1981 à Alemanha. A poesia permaneceu como um interesse central em minha vida. Até 1948 escrevi em alemão, e depois em inglês. A partir de 1981 regressei a minha língua materna. ${ }^{62}$

O retorno ao estranhamento familiar da pátria e à familiaridade estranha de sua língua materna, liberou uma criatividade poética em desenvolvimento contínuo que persistiu até idade avançada e que capturou em seus livros de poesia Zeitwechsel (1987) ${ }^{63}$, Im Anblick

59 Hessel, Stéphane: Indignez-vous! Montpellier: Indigène Editions 102010, p. 9.

60 Sobre la importancia de Emma Kann ver Ette, Ottmar: “Ein stets sich erneuerndes Buch' Warum es an der Zeit ist, Emma Kann zu entdecken”. En: Orientierung (Zürich) LXXI, 8 (April 2007), pp. 93-96.

61 Ver sobre isso a breve relação de Emma Kann na revista Mnemosyne (Klagenfurt) 24 (1998), p. 6.

62 Ibid., p. 7.

63 Kann, Emma: Zeitwechsel. Gedichte 1981 - 1985. Konstanz: Hartung-Gorre Verlag 1987. 
des Anderen (1990) ${ }^{64}$, Strom und Gegenstrom (1993) ${ }^{65}$, Im weiten Raum (1998) ${ }^{66}$ e também na forma de seus fragmentos autobiográficos, não publicados até hoje. A eleição do gênero, sua idade avançada e sua cegueira podem ter contribuído para que essa poeta, que regressou, não tenha encontrado com facilidade, em suas leituras públicas, esse acesso a um público mais amplo que lhe correspondia. Também por isso, diante do grande número de poemas inéditos, ainda há um tesouro por ser resgatado.

Em seu poema "Regresso à língua alemã" publicado já em 1981, fica claro que com "regresso" não se refere a um caminho de retorno, mas a um caminho em direção a uma língua que desde a fuga da poeta se transformou fundamentalmente. É um regresso a um estranhamento familiar, como se manifesta nos versos iniciais do poema: a língua como forma de comunicação de uma apatricidade inquietantemente acolhedora (unheimlich heimeligen Heimatlosigkeit). E o poema como forma de condensação de uma língua sobre uma língua que há muito tempo já passou, e que, no entanto, não pode deixar de ser:

Quando regresso à língua alemã,

Não é à língua que eu conhecia,

Quando deixei essa terra.

Ainda se submetem as palavras às orações

Como então, como sempre.

Mas as fontes, das quais brotam as palavras,

As invisíveis, mudaram.

As rochas antigas se derrubaram.

Feitos, penas, lembranças

Criaram um novo cascalho.

A chuva cai.

A água brota de novo para cima

Através de estratos transformados. ${ }^{67}$

64 Kann, Emma: Im Anblick des Anderen. Gedichte 1989. Konstanz: Hartung-Gorre Verlag 1990. 65 Kann, Emma: Strom und Gegenstrom. Gedichte. Konstanz: Hartung-Gorre Verlag 1993.

66 Kann, Emma: Im weiten Raum. Gedichte 1992 - 1996. Konstanz: Hartung-Gorre Verlag 1998.

67 Kann, Emma: “Heimkehr zur deutschen Sprache”. Em: Exil (Frankfurt am Main) VI, 1 (1986), p. 75. 
A língua como forma de circulação do líquido vital. Como acontece com frequência na poesia de Emma Kann, são as imagens das montanhas e os picos, da terra e da água, as que aparecem integradas em uma circulação natural da vida. Contudo, o que aparenta ser imutável está exposto a um processo de erosão que é tão irreversível como a própria vida: a desterritorialização da pátria da língua permite reconhecer que a língua materna está entrelaçada translingualmente com "The Land of My Childhood" (O país de minha infância) ${ }^{68}$, um texto de Emma Kann publicado em inglês, e que não existe além do tempo e do espaço. O poema marca o desafio translingual que a poeta cega se autoimpõe.

O nome da autora aparece no final do segundo verso - como uma distante assinatura do tempo - conjugado no passado da primeira pessoa singular: "eu conhecia" ("ich kannte”). O retorno de Ulisses (feminino) é um retorno ao desconhecido e, ainda mais, ao próprio como desconhecido. É verdade que a força da tempestade que sopra do Paraíso - para citar Walter Benjamin - a diminuiu um pouco, mas o regresso ao Paraíso da infância, ao jardim das expectativas e das esperanças, como evocam as tesselas autobiográficas da poeta, não é mais possível.

E ainda assim, essas imagens se mantêm continuamente presentes. Assim se nomeia seu ainda inédito Mosaico Autobiográfico:

O Jardim de Emmel era um pequeno paraíso com flores, árvores frutíferas, hortas, com grandes e douradas abóboras no outono e uma selva completa de groselhas vermelhas e espinhosas. Em alguns lugares estava o Jardim muito organizado e em outros deixado quase em estado natural.

Atrás da pequena casa branca se encontrava um gramado retangular, divido em partes iguais por um caminho que o atravessava inteiro. Em três dos cantos do gramado se erguiam grandes e velhas macieiras. Seus ramos se aproximavam tanto, que na época de sua floração quase construíam um teto branco sobre o gramado. No quarto canto se encontrava uma bomba de água de ferro, velha e em desuso, em cuja parte mais alta se aninhavam andorinhas. ${ }^{69}$

Um caminho de retorno a esse jardim é, obviamente, impossível; a retrospectiva traçada por Emma Kann é tão sutil, que desde muito cedo se pode ver a onda do nazismo penetrando nesse paraíso para arrasá-lo completamente. De tal modo que a poeta, como Giorgio Caproni, poderia ter dito ao chegar na Alemanha: "Estou de volta ali / onde nunca estive."70

A escrita de Emma Kann é uma busca incessante e ao mesmo tempo perpétua, por seguir a dialética da apatricidade através de "estratos transformados" e dar a ela uma ex-

68 Cfr. Kann, Emma: “The Land of My Childhood”. Em: Exil (Frankfurt am Main) VI, 1 (1986), p. 74.

69 Kann, Emma: “Emmeles Garten”. En: Autobiographisches Mosaik, p. 2. Ver sobre isso meu estudo "In Emma Kanns Garten" (no prelo). Cito uma das fotocópias que a escritora me enviou de seu manuscrito inédito; todos os textos inéditos de Emma Kann se encontram facilmente acessíveis no arquivo da autora em "Deutschen Exilarchiv 1933-1945 der Deutschen Nationalbibliothek" en Francfort del Meno.

70 Caproni, Giorgio: Poesie, p. 392. 
pressão linguística, em que sobreviver e estar a salvo se tornam a única pátria a ser pensada, a única pátria a ser vivida, a única pátria a ser escrita. Não apenas o país, que em sua disposição natural está sujeito a contínuas variações, mas também a língua, cujo saber circula em outros meios, permitem perceber como ilusório qualquer simples return, qualquer regresso: o poema solapa seu título, permite reconhecer o próprio regresso como uma nova migração.

Consequentemente, aqui não se trata de uma Return Migration no sentido estrito, ou, no melhor dos casos, de uma migração em forma de uma volta em $U$ (que regressa ao mesmo lugar) mas principal e fundamentalmente se trata de uma remigração: posto que em cada migração adicional - que leva novamente a um ponto de partida - há uma jornada que se reitera e, por isso mesmo, uma nova jornada. Seja esta migração voluntária ou involuntária, sempre ressoa nela uma promessa, uma esperança de redenção. E se as imagens de um país parecem igualar-se na superfície, devemos ter presente que somente quando o poema - a língua sobre a língua - consegue filtrar condensadamente aquela coisa invisível de que fala o poema "Regresso à língua alemã", é que se alcança esse saber, que ainda é fruto do saber do Paraíso, da árvore do conhecimento. Na língua circula sempre, "através de estratos transformados”, um saber do paraíso, ou seja, um saber da expulsão.

\section{CAMINHOS DE UM LUGAR A OUTRO, DE MIGRAÇÃO PARA MIGRAÇÃO}

Tanto seus poemas publicados, como grande parte de sua obra até hoje inédita, demonstram que Emma Kann é uma representante das literaturas sem residência fixa, que especialmente no início da quarta etapa de globalização acelerada, ou seja, desde fins dos anos oitenta do século XX, estabeleceram um lugar com peso cada vez maior dentro das literaturas do mundo ${ }^{71}$. Em seus movimentos oscilantes, que atravessam continuamente diversos sistemas literários regionais, nacionais e também continentais, as literaturas sem residência fixa abriram um espaço de movimento entre a literatura nacional e a literatura mundial, que não permite compreendê-las pela perspectiva de uma única literatura nacional, como tampouco a partir de uma única área. Estão comprometidas com poéticas do movimento, cujo desenvolvimento na teoria literária está ainda por fazer-se.

Neste contexto, certamente podemos também compreender a obra do poeta José F.A. Oliver, filho de imigrantes andaluzes e nascido na Floresta Negra em 1961, como uma forma de expressão poética de uma literatura sem residência fixa. As línguas da lírica de Oliver são tanto o alemão (certamente, até agora, o ponto central de sua construção poética) quanto o espanhol, tanto o alemânico como o andaluz, com as quais, por exemplo, a edição trilíngue de seu livro de poesia Duende ${ }^{72}$, em que se dão numerosas e intensas combinações entre a "Ballade vom Duende" do alemão padrão, a "Balada del Duende" espanhola e a "Duendelied" de Baden, podem ser classificadas como uma poética do movimento trans-

71 Ver: Ette, Ottmar: “European Literature(s) in the Global Context - Literatures for Europe”. En: D’haen, Theo / Goerlandt, Iannis (Hg.): Literature for Europe? Amsterdam - New York: Rodopi 2009, p. 123-160.

72 Oliver, José F.A.: Duende. Meine Ballade in drei Versionen: Die Ballade vom Duende - La balada del Duende - S Duendelied. Gutach: Drey-Verlag 1997. 
lingual. Esta dimensão translingual que atravessa diferentes línguas se encontra também onipresente em cada um dos volumes de poemas que, à primeira vista, tinham sido escritos em alemão padrão.

A poesia desse poeta, muito vinculada com sua região de nascimento, deve ser analisada, à continuação, não tanto na direção das literaturas sem residência fixa ${ }^{73}$, mas apontando em direção ao tema que aqui escolhemos e nos fazendo questionar que sabersobreviver específico a poética de Oliver oferece sobre o problema da migração. Ou melhor, que relações há entre a palavra (Wort), o lugar (Ort) e o partir (Fort)?

Essa problemática já permeia Gastling, seu livro precoce, publicado em 1933, onde bem no início da resenha na contracapa, se diz que José Oliver: "Nascido em 1961 em Hausach em Kinzigtal (Floresta Negra), filho de trabalhadores espanhóis temporários, que em 1960 emigraram de Málaga (Andaluzia) para a República Federal da Alemanha, então sem ter consciência de que imigravam." ${ }^{74} \mathrm{O}$ uso do termo problemático (e problematizador) de "trabalhadores temporários" no paratexto, abre o jogo com todas as variantes de hospitalidade encontrada e inventada, mas sobretudo vivenciada e vivida e que já impregnam o poema de abertura:

\author{
contado \\ nascido no país \\ por acaso um \\ dividido \\ chegado \\ partido \\ hóspede ${ }^{75}$
}

O título angezählt, extraído da linguagem do boxe e traduzido aqui como "contado", distingue o boxeador no momento em que, posto contra as cordas ou caído sobre a lona, se aplica a ele a contagem protetora, e deixa claro desde o início que o papel do "hóspede" / "Gastling" - palavra que em espanhol expressa a estranha dualidade do parasitismo ou comensalismo, do que hospeda e do que é hospedado e em alemão ecoa o "Fremdling" sob o "Gastarbeiter" - é tudo menos livre de conflito. Assim, sob o hóspede e o Gastling perma-

73 Já discuti extensamente este tema em meus livros ÜberLebenswissen. Die Aufgabe der Philologie (Berlin: Kulturverlag Kadmos 2004, entre outras p. 246-251) e Zwischen WeltenSchreiben. Literaturen ohne festen Wohnsitz (entre otras, p. 261263).

74 Oliver, José F.A.: Gastling. Gedichte. Berlin: Das Arabische Buch 1993, resenha na contra-capa.

75 angezählt // ins land geboren / zufällig eins / entzweit / angekommen / aufgebrochen / gastling. Ibíd., p. 9. 
nece presente o estranho, apesar desse estranho ter nascido no país. No entanto, o princípio da natividade aparece aqui anulado, o que de nenhuma maneira é um caso particular. Com referência às reflexões de Hanna Arendt, Giorgio Agamben destacou acertadamente, de uma perspectiva biopolítica que, no século XX, a ruptura da "continuidade entre o homem e o cidadão, entre a natividade e a nacionalidade, o nascimento e a cidade" já não é possível dispensar, tanto em qualidade como em quantidade, e que o contexto da construção nacional moderna fez toda "ficção de origem"76 entrar em crise. A poesia do poeta andaluz da Floresta Negra pode ser um expoente revigorante e altamente criativo para esse tema.

O jogo com os números, com a unidade e a divisão, se abre a uma multiplicação que já tomou forma desde o título "contado": o contado (enumerado) se transforma em "contado" (a quem se aplica a contagem), e que como tal no poema se transformará, em um movimento aberto, no "contado" (narrado): no lexema "partido" (aufgebrochen) se insinua o padrão de movimento da "partida" (Aufbruch), sem que se possa reconhecer uma meta para esta partida. No chassé-croisé entre "partido" (aufgebrochen) e "contado" (angezählt) a abertura e a enumeração também se fazem audíveis, o que na micronarrativa deste poema se fará compreensível de uma maneira impressionante.

O caráter fortuito de ter nascido no país, que é o resultado de um movimento migratório que está em sua base, se ampliará ao mesmo tempo com a ajuda do paratexto e o fato de que se trata de um país que por acaso está "dividido", ou seja, um país que há muito tempo existe na forma de dois países separados. A micronarrativa das formas verbais "contado", "nascido", "dividido", "chegado", "partido", deixa claro que o fato de nascer não ficou no simples fato de chegar, mas que no poema (se) partem ou (se) partirão todos os elementos que fazem com que o hóspede, enquanto estranho, se transforme em alguém sempre de saída, que não pode parar nem descansar. O fato de haver nascido em um país, neste país dividido, que é, coincidentemente, também em um sentido histórico uma província dividida (Baden-Würtemberg), não protegeu ao filho dos "então" imigrantes, inconscientes do status pejorativo do estrangeiro ou do hóspede.

A continuação, na sequência de poemas da coletânea Gastling, no Poem a un huésped a mi confiado, se farão audíveis as línguas sob a língua e os lugares (Orte) sob as palavras (Worten). Já que o poema começa com um polissêmico “despierto" em espanhol, para o qual uma mudança para o alto alemão segue-o apenas no final do primeiro verso deste longo poema:

\section{Desperto.}

De madrugada desperto.

Desperto dos anseios.

É a noite que chega.

76 Agamben, Giorgio: Homo sacer. Die souveräne Macht und das nackte Leben, p. 140. 
Sua mão de fogo.

Chega a tocar as portas de minhas casas.

A desperto.

Mão que busca o cheiro do esquecimento.

Esquecimento transparente.

Véus fugitivos.

As águas.

Sua memória.

Oh, pardon...

Ich vergaß,

daß ich in Deutschland bin. ${ }^{77}$

Nestes versos, fortemente impregnados de poetas andaluzes como Federico García Lorca ou Rafael Alberti, se exibe uma fala diferente, que se situa no despertar e na dupla fronteira noturna - a do dia e da noite, do sonho e da vigília. Na oscilação entre ambos os polos se movimenta esta outra fala e sob o poema se torna audível o poem, onde a seguinte tradução do fragmento se introduz como uma desculpa que se expressa - no meio do caminho entre o alemão e o espanhol - com o lexema francês "pardon". Se a segunda estrofe está reservada tanto para uma tradução como para um deslocamento dos versos espanhóis iniciais, da mesma forma aparecerão mais de uma vez no transcurso do poema, as palavras sob as palavras, as línguas sob as línguas, os movimentos sob os movimentos, os versos sob os versos. Como leitor ou leitora, não se pode estar certo da língua que se tem diante dos olhos.

Por sua vez, isso quer dizer, como no poema inicial desse volume, que não há uma "procedência" inequívoca, que não há uma filiação territorial, nacional ou idiomática singular, que será consequentemente infringida. No entanto, onde não há uma procedência, mas procedências, onde não há origem, mas origens, conceitos como "regresso" ou Return Migration se estremecem e levam ad absurdum. Porque, a partir de onde se deveria considerar essas origens e até onde deveríamos regressar? Qual seria o ponto de referência territorial ou linguística, em que o eu lírico se afilia a diferentes países e diferentes línguas e que estas afiliações no transcurso de sua produção poética se multiplicam ainda mais? E como

77 Tradução do texto em alemão: "oh, perdão... / esqueci / que estou na Alemanha". Oliver, José F.A.: "Poem eines mir anvertrauten Gastlings". En: Gastling, p. 10. 
poderia a atitude "de estar de saída" desse eu lírico configurar uma meta única, quando as inumeráveis procedências colocam em jogo um porvir não menos inumerável?

Em seu volume de poemas austernfischer marinero vogelfrau, publicado em 1997, José F. A. Oliver condensou literariamente, mais de uma vez, um padrão de movimento desse tipo. Um exemplo especialmente "denso" aparece no poema "refugiados mendigam prorrogação" (flüchtlings aufschub betteln), onde diz:

\author{
refugiados mendigam prorrogação \\ Nós poderíamos simplesmente fugir \\ De um lugar a outro / e ficar. ${ }^{78}$
}

Também aqui, em um "nós” coletivo, se faz presente uma figura móvel, que leva "de um lugar a outro" e que não obedece a nenhuma direção de movimento claramente determinada. O próprio movimento também pode ser suspenso em qualquer momento ou em qualquer lugar e transformar-se em estadia (temporal). A estrutura móvel do refugiado está submetida nisso de maneira mais radical que a do hóspede à dinâmica do "contado", já que necessita uma prorrogação e mendiga uma prorrogação. Essa prorrogação como adiamento de novos movimentos de fuga é com tudo, nem mais e nem menos do que um descanso no movimento descontínuo, cuja vetorialidade dificilmente é possível calcular através de movimentos inequívocos dotados de sentido e submetidos a direções comuns. O refugiado é, nesse sentido, a exacerbação do estrangeiro e do hóspede, que também expressa com clareza seus padrões de movimento.

A prorrogação como uma dimensão temporal, se traduz nesse sentido no espaço como refúgio. E no volume de poemas publicados em 2006 com esse mesmo nome (Refugio - Unterschlupf) novamente o poema inicial “050804" se torna o sismógrafo dos movimentos contínuos que possuem um caráter migratório e nômade:

\author{
ido pelo camino secreto \\ ignorada a fronteira. Os olhos \\ escondidos atrás dos passaportes \\ na alfândega I data
}

I carimbos borrados

\& movido pelo medo. Domesticado ${ }^{79}$

78 Flüchtlings aufschub betteln // wir könnten doch nur fliehen / von ort zu ort / und bleiben. Oliver, José F.A.: austernfischer marinero vogelfau. Liebesgedichte und andere Miniaturen. Berlin: Verlag Das Arabische Buch 997, p. 17.

79 Den schleichweg gegangen / die grenze missachtet. Die augen / hinter den päassen verborgen // im zöllner I datum 
Todo o volume apresenta movimentos de viagem entre Alexandria e Berna, entre Casablanca e Innsbruck, entre Rabat e Zurique, que imitam padrões de movimento dos refugiados e dos hóspedes. Modelam uma vivência de leitura invertida, que acredita distinguir por todas as partes as "vozes de procedência" mais diferentes - como o poema de mesmo nome $e^{80}$-, às quais sempre se associam outras novas. Os padrões de movimento se transformam em padrões de compreensão, os controles de passaporte e os carimbos se tornam comprovantes de itinerários, que em sua busca de refúgio e extensão conseguem estabelecer relações entre espaços de fuga: movimentos errantes e apátridas que remetem a outros e mais antecipados movimentos errantes e apátridas. Não serão esses padrões de movimento aqueles que já conhecíamos a partir de Gênesis e de Caim? E não se assentam nesse espaço tempo que no livro de poemas Fahrtenschreiber (Tacógrafo ou literalmente Escritor de viagens) de 2010, sob o título "dichter ort VIII" (que pode ser duplamente traduzido como "poeta lugar VIII" ou "lugar denso VIII") se expressam como figuração poética?

Entre o céu \& a terra

A fratura das figuras do tempo

Entre a terra o céu ${ }^{81}$

O poeta como tacógrafo e escritor de viagens, tal como Gilgamesh, não está atado à superfície da terra, mas oscila como a figura de movimento mesopotâmica no cosmo de toda a criação, entre o céu e a terra. O poema "quarteto" de José F.A. Oliver, colocado no contexto aqui esboçado de suas figuras de movimento do hóspede, do estrangeiro e do refugiado, poderia facilitar a passagem a outra autora, cujas tacografias também podem ser compreendidas como literatura sem residência fixa. Este "quarteto" diz assim:

mas a palmeira das pombas

mas a cálida paz do sol de dezembro

mas o desequilíbrio da palmeira \& calor

de paz \& a pomba ${ }^{82}$

/ I stempelverschwimmen / \& regung von angst. Domestiziert. Oliver, José F.A.: “050804”. En: unterschlupf. Gedichte. Frankfurt am Main: Suhrkamp 2006, p. 9.

80 Ibid., p. 46.

81 zwischen himmel \& erde // die fraktur der Zeitfiguren // zwischen erde himmel. Oliver, José F.A.: fahrtenschreiber. Gedichte. Berlin: Suhrkamp Verlag 2010, p. 46.

82 aber die taubenpalme / aber die friedenswärme der dezembersonne / aber das ungleichgewicht von palme \& wärme / aus frieden \& taube. Oliver, José F.A.: "vierzeiler". En: unterschlupf, p. 68. 
Porque aqui a palmeira, enraizada à terra, graças à pomba, que voa em direção ao céu, é posta em um desequilíbrio, em que a proximidade dos contrastes semânticos se dinamiza continuamente através da vinculação entre o tetrassílabo "Taubenpalme" (palmeira de pombas) e o quarteto. O impulso para frente do poema mediante a recorrência ao lexema "mas" desdobra esse "desequilíbrio" até chegar a uma relação paradoxal, relação de quebra, em que a paz e a pomba se desprendem de sua convencionalidade emblemática: a pomba empreende voo em múltiplos sentidos.

Dinamizações similares e vetorialidades análogas aparecem em um romance sob o título Tauben fliegen auf, atravessado por movimentos continuamente erráticos:

(E por um longo momento fico só, vejo os trilhos, como se cruzam, eu, a que ama observar os viajantes por uns segundos pelas noites, às vezes seguir o destino de um rosto relaxado ao qual a esperança se aproxima pela fronte, poderia passar horas sentada aqui, viajar a todas as partes, até onde ainda não estive, a Barcelona com o Talgo ${ }^{83}$ e logo a Madrid, Lisboa, não sou uma viajante, mas sim alguém que vai e não sabe se algum dia voltará, e cada vez que parti, arrumei meu quarto com vergonhosa perfeição: lavo os vestidos que não levo comigo, os dobro ordenadamente e os penduro no roupeiro; cubro meu espelho, para que não veja meu quarto sem mim, minha escrivaninha vazia, a estante de livros organizados alfabeticamente, a cama recém feita, sempre me preparei para uma partida sem retorno, quando viajávamos a Voivodina, e essa foi por longo tempo a única direção na qual viajei). ${ }^{84}$

Movimentos, em direção para onde também olhamos: com esses pensamentos postos entre parêntesis, quase exteriorizados pela passagem, reflete Ildiko Kocsis, a narradora em primeira pessoa do romance Tauben fliegen auf, de Melinda Nadj Abonji, reconhecida em 2010 com o Prêmio Alemán del Libro, sobre sua própria posição que não está fixada em um lugar ou país, mas a movimentos e padrões de movimento. O objetivo desses movimentos? Sair do refúgio em direção à extensão, viajar a todas as partes, onde nunca esteve. O sujeito dessas viagens? A que vai sem saber se algum dia retornará - uma refugiada, uma hóspede/ visitante, não uma figura trágica, mas muito longe do Éden.

Porque a protagonista, retratada com muito amor pela autora nascida entre a minoria húngara de Voivodina, na Sérvia, que migrou com seus pais para a Suíça e que hoje faz

83 (N.T.) Talgo, S.A. é uma fabricante espanhola de trens de passageiros interurbanos, padrão e de alta velocidade.

84 „(Und einen Moment lang bin ich für mich allein, sehe die Schienen, wie sie sich kreuzen, ich, die es liebt, nachts Reisende ein paar Sekunden lang zu beobachten, manchmal dem Glück eines gelösten Gesichtes zu folgen, das einer Hoffnung entgegenfährt, ich könnte stundenlang hier sitzen, um überallhin zu fahren, wo ich noch nie war, nach Barcelona, mit dem Talgo und weiter nach Madrid, Lissabon, ich bin keine Reisende, sondern eine, die weggeht und nicht weiss, ob sie jemals zurückkommt, und jedes Mal, wenn ich weggefahren bin, habe ich mein Zimmer peinlich genau aufgeräumt, habe meine Kleider, die ich nicht mitgenommen habe, frisch gewaschen, ordentlich zusammengelegt oder im Schrank aufgehängt; meinen Spiegel habe ich abgedeckt, damit er das Zimmer ohne mich nicht sieht, mein leeres Schreibpult, das alphabetisch geordnete Bücherregal, das frisch bezongene Bett, ich habe mich immer auf eine Abreise ohne Rückkehr vorbereitet, wenn wir in die Vojvodina gereist sind, und das war lange Zeit die einzige Richtung, in die ich gefahren bin.)“Nadj Abonji, Melinda: Tauben fliegen auf. Roman. Salzburg - Wien: Jung und Jung 2010, p. 137 s. Uma versão ao espanhol aparecerá em novembro de 2011 com o título Las palomas emprenden el vuelo pela editora barcelonesa El Aleph. 
parte das grandes apostas da literatura em alemão do país dos Alpes, não se sente presa a nenhuma residência fixa e está sempre a ponto de abandonar sua casa na Suíça, preocupada por deixar em ordem e atrás de si, tudo aquilo que representa e reflete como em um espelho, sua vida neste país, para onde seus pais imigraram por razões políticas e muito antes da derrubada da República Popular da Iugoslávia. Ao mesmo tempo, tudo acontece diante do cenário de acontecimentos sangrentos de Sarajevo, com a consciência da derrubada vertiginosa de um saber sobre a convivência, cuja limitação sistemática culminou na ex-Iugoslávia em guerra civil, no fratricídio coletivo sem o signo de Caim.

Ildi - o nome que recebe a jovem por parte de sua família e de seus amigos - é uma figura móvel: ela assimilou seus próprios movimentos tanto quanto os de sua família, os incorporou e encarnou em uma configuração que só pode ser apreendida vetorialmente, em movimento, tal como podemos encontrá-la com frequência naquelas formas de expressão literária do século XX e XXI que podemos denominar como literaturas sem residência fixa. Ildi e Melinda Nadj Abonji são, como José F. A. Oliver e seu eu lírico, filhos de uma migração que refere uma procedência destacada - nela Voivodina, nele Andaluzia -, mas que de fato permitem reconhecer as precedências e futuros mais diferentes. Seus pais deixaram como legado (e, portanto, é transgeracional) uma vetorialidade de todos os processos de compreensão, a que se expressa literariamente condensada nos lugares sob os lugares e nas palavras sob as palavras. Nenhuma história espacial estática, que se oriente a fronteiras fixas de países e nações, mas uma história em movimento, que compreenda o espaço como uma consequência sempre móvel que a atravessa e, portanto, como um padrão de movimento constituído vetorialmente, pode considerar essas histórias. Não é possível pensar na Suíça sem pensar em Voivodina, assim como não é possível pensar na Floresta Negra sem Andaluzia.

Certamente, seria um extremo simplista falar de uma escrita autobiográfica em José Oliver e em Melinda Nadj Abonji: o que é encontrado está muito ampliado pelo que é inventado, tudo está demasiadamente alicerçado em uma vivência que se serve tanto dos descobrimentos como das invenções. Os fragmentos das histórias de vida que se mostram como histórias em movimento não modelam apenas uma interação de poesia e verdade, de ficção e ficcionalidade, mas formam um jogo complexo entre o encontrado, o inventado e o vivido $^{85}$. Na passagem recém mencionada, o quarto, com seus numerosos livros, com suas numerosas ficções, se transforma de uma maneira altamente friccional em um espaço vital de experimentação de uma vida, que não é possível apreender nem compreender como algo distinto dos movimentos erráticos (como a garçonete Ildi na "Cafeteria Mundial”).

Já no incip deste romance, no qual pela primeira vez vivenciamos a paisagem de Voivodina - que em sua ensolarada trivialidade contrasta fortemente com os Alpes Suíços - a partir de um olhar para o interior de um Chevrolet em movimento, deixa clara essa conexão retrospectiva de toda compreensão aos momentos em movimento. Os padrões de movimento que percorrem todo o romance, configuram dessa forma um texto em que a pequena cidade suíça está sempre presente na pequena cidade servia, Suíça sempre em Voivodina e Voivodina na Suíça. Como seria possível um verdadeiro retorno a uma Voivodina que

85 Sobre essa tríade, ver Ette, Ottmar: ZusammenLebensWissen, p. 32. 
ainda não soubesse nada da Suíça? Como poderia aqui o retorno não levar a um lugar que é sempre o mesmo, mas ao mesmo tempo sempre diferente? A possibilidade do retorno se nomeia, a impossibilidade de sua realização é, no entanto, palpável com as mãos. Para trás é a pergunta pelos muitos aonde.

Como nos poemas de José F. A. Oliver, também nesse texto narrativo os processos de tradução permeiam tudo: uma língua se abre a outra língua, que por sua vez se abre a muitas outras. Esses processos de tradução não se referem somente ao nível intralingual ${ }^{86}$, quando, por exemplo, em visita aos mortos, dos quais já se diferenciam, se filosofa sobre a condição de ser diferente ${ }^{87}$, também não é apenas ao nível intralingual, quando, por exemplo, Dalibor, o jovem de Dubrovnik que fugiu à Suíça, e a narradora em primeira pessoa apaixonada por ele, são mediados por um dicionário mutilado ${ }^{88}$, que somente permite a interação em uma confusão de idiomas entre o húngaro e o servo-croata proibido pelos pais, entre o alto-alemão tanto quanto o alemão suíço e o inglês, e que, no entanto, os diversos processos de tradução conseguem levar a cabo uma comunicação íntima e saudável. O tecido textual não seria pensável sem todos esses processos translinguais, nos quais se cruzam e transformam mutuamente diversas línguas, que obviamente também se referem à autora que não escreve em sua língua materna, mas acima de tudo destaca os materiais linguísticos que constroem o romance. Aqui o alto-alemão se torna transparente através do alemão suíço, através do húngaro, mas também através de outras línguas, de tal modo que a estruturação anagramática ${ }^{89}$ da narrativa se torna reconhecível e cujos movimentos se colocam no centro a partir do título: Tauben fliegen auf.

O romance de Melinda Nadj Abonjis delineia com grande precisão e meticulosidade os mecanismos de exclusão que afetam a todos os seres humanos que não obedecem ao princípio da natividade e que "não são daqui". Esses mecanismos de exclusão comumente se enfeitam com racismos ocultos, como as apreciações pejorativas sobre a anatomia da região occipital dos habitantes dos Balcãs, ${ }^{90}$ mas sempre transmitidas e transmissíveis verbalmente. Os insignificantes movimentos dos que visitam a "Cafeteria Mundial", que antigamente era administrada pela família suíça Tanner, mas que agora pertence aos estrangeiros Kocsis, exibirá e levará até o extremo da inofensividade e insignificância destes diminutos movimentos linguísticos, estes tropismos da xenofobia, até que a narradora em primeira pessoa revele "que a simpatia, a respeitabilidade, o controle, a cortesia dos "verdadeiros" suíços é uma máscara, e de fato, impenetrável”91. A Suíça não se tornará pátria, a narradora permanece refugiada, certamente estrangeira, hóspede, no melhor dos casos: ainda que (e principalmente por isso) se comporte da maneira menos chamativa e insignificante, apenas

86 Sobre esses conceitos, ver: Jakobson, Roman: “On linguistic aspects of translation”. Em: Selected Writings. II. Word and Language. The Hague - Paris: Mouton 1971, p. 260.

87 Nadj Abonji, Melinda: Tauben fliegen auf, p. 299 s.

88 Ibid., p. 184 .

89 Ver: Starobinski, Jean: Wörter unter Wörtern. Die Anagramme von Ferdinand de Saussure. Übersetzt und eingerichtet von Henriette Beese. Frankfurt am Main - Berlin - Wien: Ullstein Verlag 1980.

90 Nadj Abonji, Melinda: Tauben fliegen auf, p. 241.

91 Ibid., p. 283. 
para não chamar a atenção, para não ser percebida.

Mais de uma vez se evocam no romance cenas da guerra dos Balcãs, se exibe o enorme absurdo da limpeza étnica, se retratam as crueldades do sítio de Sarajevo. A sangrenta ruptura da Iugoslávia modela a lâmina contemporânea sobre a qual se representa a derrubada, historicamente mais bem documentada, de um saberconviver em que a diegese situada na Suíça será intercalada.

A protagonista - e com ela o romance - já não está na busca por um sabersobreviver (ÜberLebenswissen), mas por alicerces de uma convivência futura, pelas possibilidades e fronteiras de um saber sobre e na convivência, em que ser diferente não leve à exclusão, nem à morte, nem sequer à própria condição de ser diferente. Tauben fliegen auf - e a pomba não por acaso é um tema que sempre retorna, que atravessa o romance e que insere nele isotopias sobre o ser caçado, o ser devorado, mas também sobre a paz e o livre movimento desdobra aqui, no nível linguístico, com toda a potência e também com uma sutil violência, aquela busca de uma convivência que não tem por quê terminar em cada momento em uma declaração de guerra.

Nessa proposta prospectiva, que se pergunta pela convivência futura, nos encontramos com um olhar baseado em constantes trocas de olhar, com uma língua baseada em constantes intercâmbios linguísticos (verbais), com uma cultura baseada em constantes traduções que buscam tornar-se conscientes tanto do passado como do futuro. É uma literatura que aponta em direção à vida, mesmo quando - ou principalmente por isso - tenha a seus mortos muito presentes; uma literatura que gera a força de seu trabalho sobre a história, de seu trabalho sobre a guerra, por um futuro, precisamente ali onde em primeira instância, não esperaríamos: por exemplo, no cemitério.

No romance, as árvores do cemitério, que parecem estar fortemente enraizadas, vêm de todos os lados e inserem mais uma vez a extensão e a abertura nessa extraordinária narrativa. Assim, Tauben fliegen auf termina com o olhar em direção a uma vida em que a condição de ser diferente inaugura a diferença do futuro; um futuro em que um lugar determinado permanece consciente sobre os outros lugares, as outras palavras e as outras vidas:

Caminhamos através do cemitério Sihlfeld, que é tão belo, porque é incomumente tão grande e extenso, admiramos as árvores que têm espaço para crescer, enormes carvalhos e plátanos, todo tipo de castanhas, que já estavam completamente sem folhas, uma delicada avenida de bétulas, inclusive descobrimos Ginkgos, cujas folhas amarelas e douradas forravam a trilha de cascalho; até que chegamos à vala comum, colhemos os misteriosos e coloridos seres que acabavam de cair das árvores, no momento em que estão mais bonitos, e os colocamos junto às flores sobre o túmulo; neste dia azul de novembro pensamos em nossos mortos, tias avós e tios avôs, em nossos avós que jamais conhecemos, a mãe de mamãe e Papuci, para eles, Mamika, entoamos uma canção e em seus nomes pedimos que os vivos não morressem antes de seu tempo. ${ }^{92}$

92 „Wir sind durch den Friedhof Sihlfeld gegangen, der so schön ist, weil er ungewöhnlich gross und weit ist, wir haben Bäume bewundert, die Platz haben zum Wachsen, riesige Eichen und Platanen, alle Arten von Kastanien, die bereits ganz nackt waren, eine zierliche Birkenallee, sogar Ginkgos haben wir entdeckt, deren gelb-goldene Blätter den Kiesweg säum- 
Na poliglosia translingual das literaturas sem residência fixa de Emma Kann, de José F.A. Oliver ou de Melinda Nadj Abonji aparece uma literatura que é profundamente europeia, mesmo que não em um sentido aditivo em que encontramos diferentes literaturas nacionais, uma ao lado da outra, mas em sentido radical, e que, além disso, aponta em direção a uma convivência na paz e na diferença. E embora a migração seja um tema que permeia o texto, devemos tirar de seus alicerces, cuidadosa e decididamente, qualquer tipo de ideia sobre um retorno ou sobre uma simples Return Migration. No horizonte não há nenhum Paraíso ao que regressar, e mais: cada promessa na qual se sustenta tal ingresso, se apresenta como perigosa, como um problemático ideologema. Não era o discurso nacionalista que prometia o regresso a um antigo reino, que desencadeou a guerra civil na Iugoslávia? Já não foi utilizado com tanta frequência na história humana o retorno a uma "origem" como legitimação da violência e da guerra? A esse tipo de formas essencializantes de regresso, do retorno a um reino, as literaturas sem residência fixa opõem uma abertura radical dos caminhos do futuro, já que o que se distribui espacial e historicamente como regresso, se pode compreender em um sentido histórico-móvel como uma recaída em um ideologema queimado, em fatais ideologias. Essas ideologias, impostas violenta e monologicamente, trazem consigo, com muita frequência, somente a morte.

\section{CAMINHOS NAS PROXIMIDADES DO PARAÍSO}

No ano de 2009, se publica pela primeira vez o romance Au pays, ambientado em Paris e Tânger entre abril de 2005 e julho de $2008^{93}$. Seu autor, Tahar Ben Jelloun ${ }^{94}$, que nasceu em Fez em 1944 e viaja constantemente entre Marrocos e Paris, criou um texto narrativo que se entrelaça com seu romance Partir (2006), que dá voltas em torno do tema da partida ao desconhecido ${ }^{95}$, e que precisamente aborda o problema do regresso e da Migration Return, de forma obsessiva. Mohamed, o protagonista do romance Au pays (que não sem fundamento foi traduzida ao alemão como Regressar (Zurückkehren) $\left.{ }^{96}\right)$, trabalha durante quatro déca-

ten; bis wir vor dem Gemeinschaftsgrab standen, haben wir die wundersamen, farbigen Wesen gesammelt, die gerade dann von den Bäumen fallen, wenn sie am schönsten sind, und wir legten sie mit den Blumen auf das Grab; an diesem blauen Novembertag dachten wir an unsere Verstorbenen, Grosstanten und Grossonkel, an unsere Grosseltern, die wir nie kennengelernt haben, Mutters Mutter und Papuci, für Sie, Mamika, haben wir ein Lied gesungen, und in Ihrem Namen haben wir darum gebeten, daß die Lebenden nicht vor ihrer Zeit sterben."

Ibid.,

p. 315 .

93 Ben Jelloun, Tahar: Au pays. Paris: Gallimard - folio 2010, p. 169.

94 Sobre Tahar Ben Jelloun consultar Spiller, Roland: Tahar Ben Jelloun. Schreiben zwischen den Kulturen. Darmstadt: Wissenschaftliche Buchgesellschaft 2000; também, do mesmo autor: "Wegmetaphorik und »mise en abyme«bei André Gide und Tahar Ben Jelloun”. Em: Gelz, Andreas / Ette, Ottmar (Hg.): Der französischsprachige Roman heute. Theorie des Romans - Roman der Theorie in Frankreich und der Frankophonie. Tübingen: Stauffenburg Verlag 2002, pp. 231-246.

95 Ben Jelloun, Tahar: Partir. Paris: Gallimard 2006. Uma versão espanhola deste texto, com o título bajo Partir foi publicada no fim de 2006 pela editora El Aleph de Barcelona.

96 Ben Jelloun, Tahar: Zurückkehren. Roman. Aus dem Französischen von Christiane Kayser. Berlin: Berlin Verlag 2010. 
das, uma vida inteira, como trabalhador recrutado originalmente em sua cidade natal, pela Renault em Paris, a fim de realizar seu grande sonho: regressar a sua pátria, construir uma grande casa na cidadezinha e ali reunir-se com sua família completa, principalmente com os filhos, que se tornaram infiéis. Por consequência, o sonho a que o simples trabalhador marroquino se entrega, é duplo: o sonho de retorno à casa e o sonho de uma convivência perfeita e feliz. Essa visão de um ciclo vital feliz e completo parece ser realizável somente na figura circular de retorno à casa, somente no regresso à origem: Au pays.

Mohamed não é um caso particular, seu nome já mostra a representatividade dessa figura.

Enquanto isso construiu a maior casa do povoado, como nos tempos antigos. Quarenta anos na França não o tinham mudado. Ele permaneceu o mesmo. Nem a mais mínima diferença. Limpo, imaculado, sem rastros de influência. De forma natural havia permanecido hermeticamente fechado. Nada da França encontrou um lugar em seu coração ou em sua alma. Por nenhum motivo se tratava de uma decisão consciente, acordada de ante mão. Era simplesmente assim e nada parecia mudá-lo. Milhares eram como ele. Chegavam ao país de imigração como blindados, acima de tudo nenhum tipo de mistura, eles têm sua vida, seus costumes, e nós as nossas. Cada qual para si e simplesmente não há intromissão, não há invasão. Em nenhum momento teve que esforçar-se para rejeitar isso que ele chama seu contágio com Lafrance. Ele era um estrangeiro, totalmente inalcançável. Seu povo e suas tradições viviam nele e o mantinham distante da realidade. Vivia em seu mundo sem questionar-se com muitas perguntas. Referia tudo ao Islã. Minha religião é minha identidade, sou antes de tudo muçulmano e depois marroquino, e então imigrante; o Islã é meu refúgio, ele me traz calma e doa paz; é a última das religiões reveladas e encerra um extenso capítulo, que Deus começou já faz muito tempo. [...] O contrato é claro, eu trabalho, eles pagam, eu crio meus filhos e um dia regresso para casa, sim, minha casa é meu lar, minha pátria. ${ }^{97}$

Nessa longa passagem, que culmina em uma autorreflexão monológica sobre o projeto de vida representativo de milhares, é evidente que a vida do travailleur immigré na França não vinha acompanhada de uma convivência real com os franceses, mas ao contrário, era uma vida apenas de coexistência multicultural, que de maneira "total" não quer saber nada sobre ninguém mais e menos ainda de seu contratante. O monólogo é um retrospecto de quarenta anos de enclausuramento exitoso, bem blindado (blindes) contra qualquer forma de intercâmbio ou mistura: uma identidade isolada que recusa qualquer troca e que se acoberta em uma religião revelada abstrata, mesmo quando se vive de maneira pragmática.

A clara separação introduzida por Mohamed entre "nós" e "eles" recorre, assim, a uma limitada e excludente (e, reforçada a partir da experiência da xenofobia) construção de uma identidade inabalável, que por sua parte está presa religiosamente ao Islã, que por sua vez, está dominado por um conjunto de afiliações estruturadas claramente em uma hierarquia.

97 Ben Jelloun, Tahar: Au pays, p. 130 s. 
Trata-se, como propõe Amin Malouf, de um número de afiliações altamente restrito e rigidamente hierarquizado, que, no entanto, no caso de Mohamed e de outros, pelo menos não leva a identités meurtrières ${ }^{98}$; o trabalhador industrial marroquino deseja proteger-se e imunizar-se a si e aos seus, de qualquer tipo de mudança provocada por contatos exteriores. Durante suas quatro décadas na França, seu povoado é o que o habita (e não o contrário, como destaca o palavreado); e é assim como ele, ao final deste tempo, deseja regressar ao Marrocos, sem mudança alguma, e habitar seu povoado tal como o fez, quando o abandonou, sem ter nem sequer vinte anos. Mas o plano não se concretiza, não pode se concretizar.

Há um duplo problema: é verdade que Mohamed, mesmo depois de quarenta anos de sua partida, não dispõe em sua cidadezinha de nenhum tipo de eletricidade ou abastecimento de água que funcionem, mas de toda forma, o Marrocos se encontra em meio a um lento, mas profundo processo de transformação, que há tempos chegou também às formas de vida e às normas de vida de seus cidadãos. Por outro lado, as práticas de vida de seus cinco filhos, que cresceram na França, se distanciaram tanto das de seus pais, que inevitavelmente levou ao rompimento dos filhos - que por sua parte devem se encarregar dolorosamente de seus próprios papéis como segunda geração da imigração árabe - com as ideias do patriarca, que insistem em negar qualquer tipo de transformações. Mohamed já não pode manter sua família unida: seus filhos adultos, que há tempos são cidadãos franceses e independentes dele, abandonaram seu obstinado pai. Ele está convencido de que La France roubou seus filhos. E obviamente os quer de volta.

Mohamed, aposentado por idade, preserva apenas uma "ideia fixa" 99 na cabeça: Como é possível fazer o desenvolvimento voltar ao passado? Como se poderia regressar a esse sonho de vida de uma convivência feliz, abandonando todas as transformações e toda a história? Não por acaso, o romancista marroquino e ganhador do prêmio Goncourt, começa seu romance com a oração da tarde de Mohamed e seu olhar sobre uma fotografia que mostra uma "massa de gente vestida de branco" que rodeia Kaaba ${ }^{100}$. Através da obra, bem no início do primeiro dos dezoito capítulos de Au pays, se alude à peregrinação à Meca que Mohamed, enquanto fiel muçulmano, se havia imposto cheio de esperança, embora sem ter previsto nem a "promiscuidade" nem a "violência" de alguns peregrinos ${ }^{101}$ que se atiravam no chão e se pisoteavam. Ainda permanecem diante dos olhos de Mohamed as imagens abomináveis de uma multidão desatada e bárbara:

As pessoas já não estavam em si. Fora de si, caiam facilmente em transe, perdiam a consciência e desejavam assim uma morte como a que os charlatões louvavam em seus delírios. Morriam pisoteados pelos homens mais fortes, pés colossais que davam pisadas violentas para avançar, sem que nem sequer um deles se virasse para olhar o que havia feito, simplesmente seguiam caminhando com a cabeça

98 Ver Maalouf, Amin: Les Identités meurtrières. Paris: Grasset 1998. Versão espanhola, Maalouf, Amin: Las identidades asesinas. Madrid : Alianza Editorial 2004.

99 Ben Jelloun, Tahar: Au pays, p. 160.

100 Ben Jelloun, Tahar: Au pays, p. 160.

101 Ibid. 
erguida e os olhos virados para o céu, como se o céu lhes tivesse exigido esse bárbaro fervor. ${ }^{102}$

Essas cenas de violência, de cuja brutalidade Mohamed se distancia, são confrontadas pelo trabalhador da Renault que jamais se queixou em sua peregrinação, o que combina a peregrinação de um retorno à origem com a imagem sonhada de uma convivência, opondo-se, então, estas duas formas de expressão a uma identidade fanática e assassina. Não será mais o mesmo que saiu do povoado para imigrar na França e viver lá, para poder fundar e alimentar uma família mediante seu trabalho? Não será mais o fiel, filho de sua terra natal, que deveria ser, assim como para seus antepassados, o início e o fim de sua vida completa?

Assim, de acordo com suas ideias, Mohamed constrói uma casa em sua pátria, cujas dimensões fazem parecer pequeno tudo que se construiu alguma vez naquele povoado. Todo o dinheiro economizado em quarenta anos, acrescido do pedido de um crédito adicional, será investido em um verdadeiro phalanstère foureriano, que oferece espaço suficiente para todos os seus filhos e suas famílias e que, além disso, teria dentro de si um salão de orações de grandes dimensões, um hamam, uma piscina e uma grande sala comunitária para ver televisão. Sua esposa solta um grito estridente quando vê pela primeira vez o inabitável monstro que deve ser ao mesmo tempo lar e pátria de Mohamed. No entanto, o esposo explica:

Isso é muito simples, esta casa é nossa estrela, nosso bem mais precioso, cada pedra é uma gota de meu sangue, cada muro é um pedaço de minha vida, voltaremos a nos reunir e a viver como antes, como eu vivi, como viveu meu pai, só sigo o caminho traçado por aqueles que nos precederam e que sabiam melhor que nós o que é bom para nossos descendentes. ${ }^{103}$

De fato, é uma casa de regresso, de retorno ao meditado saber viver dos antepassados, que promete segurança. Eles traçaram com antecipação o que seus descendentes, no presente e no futuro, têm que seguir em um mundo que não mudou, que funciona como espaço estático.

No entanto, logo o sonho deste grande lar se tornará o pesadelo de uma grotesca e excessiva ruína e o sonho de conviver passará a ser o pesadelo do isolamento e abandono total do protagonista; seus desejos e palavras provêm de outro mundo e de outro tempo. Nem sequer um de seus filhos está preparado para aceitar o contrato transgeracional com os antepassados, renunciar a uma modernidade marcada pelo ocidente para seguir o pai até sua terra natal, para assumir normas tradicionais de vida que de nenhum modo correspondem às formas de vida sempre diversas da França. Até mesmo sua esposa, que sempre suportou tudo sem queixas, se distancia: Mohamed construiu uma casa enorme que começa a transformar-se em seu próprio túmulo, em seu mausoléu. No mundo hermeticamente isolado de Mohamed não há lugar para outras perspectivas, não há espaço para outros discursos. De modo que a convivência, como um conviver com a diferença, é impossível. 
O sonho de convivência de Mohamed, funciona somente a partir de uma única lógica: a de retorno a um espaço que já não é o que foi alguma vez, e de um regresso a um tempo que alguma vez foi, mas que já não é mais, sem conseguir misturar efetivamente o tempo no espaço ou abandoná-lo completamente. O remigrante tem prevista uma estrutura criada de uma vez por todas, na qual dispõe de todos os lugares designados a ele, mesmo sem considerar minimamente as diferenças lógicas, projetos de vida, nem as (também de outra cultura) companheiras e companheiros de vida de seus filhos. Assim, a casa não se torna a abundância nem a realização de um sonho de convivência, mas uma armadilha, para quem desejava simplesmente voltar, para quem queria simplesmente negar as transformações de espaço e tempo, como se existisse a possibilidade de regressar ao que alguma vez foi, incólume de todas as transformações. No entanto, na casa o esperam somente suas sombras, suas obsessões, sua morte.

Essa morte leva, no entanto, a uma apoteose: Mohamed, quem em seus últimos dias é perseguido por visões, e quem tomou o caminho de um místico asceta, assim que morre se transforma em um santo, cujo cadáver exala um aroma paradisíaco: "Mohamed jazia envolto por uma mortalha branca e perfumada, e exalava o aroma do paraíso". ${ }^{104}$ Seu túmulo logo se transforma em destino de muitos peregrinos. Assim, fica claro no final do romance:

O túmulo exalava um aroma paradisíaco. Em poucos dias estava coberta de uma erva de cor verde profundo. Umas flores silvestres tinham crescido. Um desconhecido plantou uma árvore trazida de muito longe. Havia sombra, frescor, paz. Assim desapareceu Mohamed Limmigri, o homem que a aposentadoria matou. ${ }^{105}$

Assim como no final do romance de Melinda Nadj Abonji, aqui também a árvore trazida de longe, que decora o cemitério, anuncia, como uma árvore do conhecimento, a vida dos mortos. Então, no final, no excipit do romance Au pays de Tahar Ben Jellouns, não é apenas a recorrência do lexema francês "paradis" o que envolve o paraíso no aroma que exala o cadáver de Mohamed, que aqui se dispõe, no meio de um pedregoso e árido deserto nos arredores da terra natal de Mohamed, com os ingredientes de um locus amoenus.

Sem dúvida alguma, Mohamed, o trabalhador industrial, o migrante, encontrou no regresso a sua terra natal, não apenas seu descanso e sua paz, mas também seu Paraíso; ainda que seja de um modo completamente diferente ao que sonhou. A ideia de um retorno se comprova como um ideograma ingênuo e alheio ao mundo, e que não resiste à prova de fogo a que a realidade interna do espaço de experimentação da narrativa de Tahar Ben Jelloun o submete. A migração de retorno ao ponto de partida se comprova sempre - e o saber experimental da literatura sobre a vida, tem inumeráveis exemplos prontos para isso - como uma migração a outro lugar, a um lugar que já não é mais o que alguma vez foi e que só pode ser porque está sendo.

O retorno de Mohamed se desenvolve mortalmente e além de qualquer possibilidade de uma convivência com a diferença. Nem na França nem no Marrocos é possível estabele-

104 Ibid., p. 168.

105 Ibid., p. 168 s. 
cer uma convivência real baseada em sua lógica. Inclusive um regresso considerado apenas de maneira histórica e espacial, se comprova como uma ilusão enganosa. O romance do autor marroquino nos exibe, como em uma sala de experimentos, a maneira como a ideia de um regresso pode se tornar uma ilusão ótica e inclusive uma armadilha mortal para todos aqueles que confiam cegamente nela. Já que o velho saber local, há muito se deslocalizou e só pode "perdurar" na medida em que se translocalize e, portanto, se transforme profundamente.

A figura de pensamento e de movimento do regresso, como espaço de condensação semântica, gera - ao considerar-se apenas em um sentido histórico-espacial - um excesso de sentido, que em última instância não pode ser utilizado teoricamente, apenas de maneira ideológica ${ }^{106}$. Como ideologema, o discurso de regresso desprende uma enorme violência. Não apenas todas as religiões monoteístas possuem o regresso à “Terra Prometida”, a um "lugar sagrado" ou a um Paraíso situado no céu, como atração excepcional, mas também as múltiplas variações dos programas e projetos políticos seculares, sejam de caráter nacionalista, fascista ou comunista.

Uma orientação em direção ao retorno como um movimento com pontos de partida e de chegada, claramente fixáveis - e que nas pesquisas anglófonas geralmente se descreve como Return Migration -, é, nesse sentido, um ideologema que aparece frequentemente no nível dos objetos (como vimos) como um espelhamento que facilmente pode nos enganar, se queremos utilizá-lo no nível de análise como instrumento (teórico literário) ou ferramenta de análise. Aqui poderia ser mais produtivo e aberto o conceito de remigração, na medida em que não integra somente a estrutura do tempo em movimento, mas, além disso, unifica as diversas lógicas dos diferentes movimentos que compreendem uma nova e renovada migração - seja de um retorno ao ponto de partida ou de uma emigração prévia.

Na partida de seu romance, Tahar Ben Jelloun, sem dúvida, joga com a ideia tão difundida pelas grandes narrativas de que os seres humanos, ao final de suas vidas, gostariam de gozar da realização, da entrada em qualquer forma de Paraíso. O autor, que oscila entre Marrocos e Paris, concedeu essa graça a seu protagonista, ainda que não pelos caminhos que Mohamed havia imaginado, sonhado ou desejado. No entanto, diante dessa singular resolução para seu "herói", aponta ao mesmo tempo, com clareza, que um saber sobre a convivência certamente não pode ser alcançado em caminhos - ainda que sejam caminhos luminosos - que submetam tudo o que concerne à convivência, sob uma única lógica. Os testemunhos literários aqui pesquisados não nos dão um sinal de advertência claro para nos protegermos de projeções histórico-espaciais territorializantes, justamente sem abandonar nossos pensamentos sobre o Paraíso perdido, com os quais começou todo movimento, toda transumância e toda história?

Não é necessário lembrar que o acesso ao Paraíso terrenal não está vetado de uma vez por todas, já que seguramente não existe um caminho de retorno, muito menos um caminho secreto e com certeza nenhum retorno à pátria que possa lançar-nos a um espaçotempo fora da história, fora da impiedosa passagem do tempo. Tampouco o conhecimento

106 Sobre a diferença entre teoria e ideologia, ver Zima, Peter V.: Ideologie und Theorie. Eine Diskurskritik. Tübingen: A. Francke Verlag 1989. 
concedido pelo fruto de uma árvore que, para nós que vivemos à leste do Éden, está já tão distante que não nos leva de volta ao Paraíso. E, no entanto, é esse conhecimento que nos empurra, sempre para novos caminhos do conhecimento - e nisto deveriam basear-se nossas esperanças e nosso orgulho - um pouquinho mais perto do Paraíso terrenal. 